\title{
Current challenges of implementing anthropogenic land-use and land-cover change in models contributing to climate change assessments
}

\author{
Reinhard Prestele ${ }^{1}$, Almut Arneth ${ }^{2}$, Alberte Bondeau ${ }^{3}$, Nathalie de Noblet-Ducoudré ${ }^{4}$, \\ Thomas A. M. Pugh ${ }^{2,5}$, Stephen Sitch ${ }^{6}$, Elke Stehfest ${ }^{7}$, and Peter H. Verburg ${ }^{1,8}$ \\ ${ }^{1}$ Environmental Geography Group, Department of Earth Sciences, Vrije Universiteit Amsterdam, De Boelelaan \\ 1087, 1081 HV Amsterdam, the Netherlands \\ ${ }^{2}$ Karlsruhe Institute of Technology, Department of Atmospheric Environmental Research (IMK-IFU), \\ Kreuzeckbahnstr. 19, 82467 Garmisch-Partenkirchen, Germany \\ ${ }^{3}$ Institut Méditerranéen de Biodiversité et d'Écologie marine et continentale, Aix-Marseille Université, CNRS, \\ IRD, Avignon Université, Technopôle Arbois-Méditerranée, Bâtiment Villemin, BP 80, 13545 Aix-en-Provence \\ CEDEX 4, France \\ ${ }^{4}$ Laboratoire des Sciences du Climat et de l'Environnement, 91190 Gif-sur-Yvette, France \\ ${ }^{5}$ School of Geography, Earth \& Environmental Sciences and Birmingham Institute of Forest Research, \\ University of Birmingham, Birmingham, B15 2TT, UK \\ ${ }^{6}$ School of Geography, University of Exeter, Exeter, UK \\ ${ }^{7}$ PBL Netherlands Environmental Assessment Agency, Postbus 30314, 2500 GH, The Hague, the Netherlands \\ ${ }^{8}$ Swiss Federal Research Institute WSL, Zürcherstr. 111, 8903 Birmensdorf, Switzerland
}

Correspondence to: Reinhard Prestele (reinhard.prestele@vu.nl)

Received: 22 August 2016 - Discussion started: 31 August 2016

Revised: 4 April 2017 - Accepted: 21 April 2017 - Published: 23 May 2017

\begin{abstract}
Land-use and land-cover change (LULCC) represents one of the key drivers of global environmental change. However, the processes and drivers of anthropogenic land-use activity are still overly simplistically implemented in terrestrial biosphere models (TBMs). The published results of these models are used in major assessments of processes and impacts of global environmental change, such as the reports of the Intergovernmental Panel on Climate Change (IPCC). Fully coupled models of climate, land use and biogeochemical cycles to explore land use-climate interactions across spatial scales are currently not available. Instead, information on land use is provided as exogenous data from the land-use change modules of integrated assessment models (IAMs) to TBMs. In this article, we discuss, based on literature review and illustrative analysis of empirical and modeled LULCC data, three major challenges of this current LULCC representation and their implications for land useclimate interaction studies: (I) provision of consistent, harmonized, land-use time series spanning from historical reconstructions to future projections while accounting for uncertainties associated with different land-use modeling approaches, (II) accounting for sub-grid processes and bidirectional changes (gross changes) across spatial scales, and (III) the allocation strategy of independent land-use data at the grid cell level in TBMs. We discuss the factors that hamper the development of improved land-use representation, which sufficiently accounts for uncertainties in the land-use modeling process. We propose that LULCC data-provider and user communities should engage in the joint development and evaluation of enhanced LULCC time series, which account for the diversity of LULCC modeling and increasingly include empirically based information about sub-grid processes and land-use transition trajectories, to improve the representation of land use in TBMs. Moreover, we suggest concentrating on the development of integrated modeling frameworks that may provide further understanding of possible land-climate-society feedbacks.
\end{abstract}




\section{Introduction}

Anthropogenic land-use and land-cover change (LULCC; for a list of abbreviations used in the paper see Supplement Sect. S0) is a key cause of alterations in the land surface (Ellis, 2011; Ellis et al., 2013; Turner et al., 2007), with manifold impacts on biogeochemical and biophysical processes that influence climate (Arneth et al., 2010; Brovkin et al., 2004; Mahmood et al., 2014; McGuire et al., 2001; Sitch et al., 2005) and affect food security (Hanjra and Qureshi, 2010; Verburg et al., 2013), freshwater availability and quality (Scanlon et al., 2007), and biodiversity (Newbold et al., 2015). Hence, LULCC is now being increasingly included in terrestrial biosphere models (TBMs), including dynamic global vegetation models (DGVMs) and land surface models (LSMs) (Fisher et al., 2014), to quantify historical and future climate impacts both in terms of biophysical (surface energy and water balance) and biogeochemical variables (carbon and nutrient cycles) (Le Quéré et al., 2015; Luyssaert et al., 2014; Mahmood et al., 2014). For example, LULCC has been estimated to act as a strong carbon source since preindustrial times (Houghton et al., 2012; Le Quéré et al., 2015; McGuire et al., 2001). Livestock husbandry, rice cultivation, and the large-scale application of agricultural fertilizers further contributed to the increase in atmospheric $\mathrm{CH}_{4}$ and $\mathrm{N}_{2} \mathrm{O}$ concentration (Davidson, 2009; Zaehle et al., 2011), turning the land into a potential net source of greenhouse gases to the atmosphere (Tian et al., 2016). Local and regional observational studies suggest impacts of LULCC on biophysical surface properties, e.g., surface albedo and water exchange, eventually affecting temperature and precipitation patterns (Alkama and Cescatti, 2016; Pielke et al., 2011).

TBMs were originally designed to study the interactions between natural ecosystems, biogeochemical cycles, and the atmosphere. The short history of implementing landuse change in TBMs ( $\sim 10$ years; Canadell et al., 2007), along with the need to include external data (e.g., maps of global cropland or pasture distribution) to represent land-use change, has led to several issues that complicate the quantification of land-use change impacts on climate and biogeochemical cycles using TBMs. For example, carbon fluxes related to land-use change that increase the atmospheric concentration of greenhouse gases are the largest source of uncertainty in the global carbon budget (Ballantyne et al., 2015; Le Quéré et al., 2015). Similarly, biophysical impacts of land-use change on climate are not yet sufficiently understood and quantified (Pielke et al., 2011). The lack of process understanding and reliable quantification of impacts can be attributed to a separated history of land-use research and land-cover research and the current offline coupling of different models, where external land-use information from integrated assessment models (IAMs) or dedicated land-use change models (LUCMs) is imposed on the natural vegeta- tion scheme of TBMs. This current land-use representation is sensitive to, in addition to other factors, the definition of individual land-use categories (e.g., what exactly defines a pasture), inconsistencies in the definition of the land-use carbon flux (Pongratz et al., 2014; Stocker and Joos, 2015), the implementation and parameterization of land use in TBMs (Brovkin et al., 2013; de Noblet-Ducoudré et al., 2012; Di Vittorio et al., 2014; Hibbard et al., 2010; Jones et al., 2013; Pitman et al., 2009; Pugh et al., 2015), the structural differences across IAMs and LUCMs (Alexander et al., 2017; Prestele et al., 2016; Schmitz et al., 2014), and the uncertainty about land-use history (Ellis et al., 2013; Klein Goldewijk and Verburg, 2013; Meiyappan and Jain, 2012).

Currently reported uncertainties of the outputs of land useclimate interaction studies may be underestimated by insufficiently accounting for the aforementioned sources of uncertainty. The current land-use representation therefore requires improvement to narrow down the uncertainty range in reported results of land use-climate studies and eventually increase the confidence level of climate change assessments. Assessments of the global water cycle, freshwater quality, biodiversity, and non- $\mathrm{CO}_{2}$ greenhouse gases would also benefit from an improved land-use representation.

The overall objective of this article is to review three important challenges faced in connecting models to assess land use-climate interactions and feedbacks, discuss the underlying mechanisms and constraints that have hampered improved representations until now, and propose pathways to improve the land-use representation. We review recent literature from the land use, land cover, carbon cycle, and climate modeling communities and support our arguments using illustrative analysis of satellite land-cover products and outputs of the land-use change model CLUMondo (Van Asselen and Verburg, 2013). Each of the following sections presents one of the three challenges we identify to be crucial in future land use-climate interaction studies and reviews the issue and its implications for the results of modeling studies, based on previously published literature and in the context of the widely applied Land-Use Harmonization (LUH) dataset published by Hurtt et al. (2011). In Sect. 5 we propose pathways to improve the current LULCC representation for each of the challenges and conclude with an outlook on future research priorities.

\section{Challenge I: spatially explicit, continuous, and consistent time series of land-use change}

\subsection{Background and emergence}

Current TBMs require consistent, continuous, and spatially explicit time series of land-use change, covering at least the period since the industrial revolution $(\sim 1750)$ to disentangle the contributions of land use and fossil fuel combustion to carbon cycling and radiative forcing (Le Quéré et al., 2015; 
Shevliakova et al., 2009). Without time series of at least this length, important legacy fluxes will be missed in the calculations. The application of discontinuous land-use change time series in TBMs to quantify the interactions and feedbacks between land use and climate would lead to large artificially induced changes ("jumps") in land use. Corresponding jumps in carbon and nutrient pools in the transition period would distort legacy fluxes working on decadal to centennial timescales, rendering the simulations useless for the quantification of climate impacts.

However, observational data on LULCC are not available on the global scale with the required temporal and spatial resolution, consistency, and historical coverage (Verburg et al., 2011). Instead, models are utilized to represent global land use and produce the required land-use change time series. Land-use modeling is typically split up into historical backcasting approaches and future scenario modeling. Both forward- and backward-looking models apply a range of different modeling approaches as well as different assumptions about drivers and the spatial allocation of landuse changes (National Research Council, 2014; Yang et al., 2014), and they are often initialized with different representations of present-day land use (Prestele et al., 2016). Thus, even the models within one community (future or historical) do not provide consistent information on land use and landuse change over time, and a variety of independent datasets on a spatially explicit or world regional level are provided to the user community (e.g., climate modeling) (see Supplement Sect. S1 and Table S1 for examples of the historical data). These historical and future datasets are not connected and consistent in the transition period and entail a variety of uncertainties (Klein Goldewijk and Verburg, 2013) (Fig. 1). In consequence, these datasets disagree about the amount and the spatial pattern of land affected by human activity. Moreover, varying detail in classification systems, inconsistent definition of individual categories (e.g., forest or pasture), and individual model aggregation techniques, amplify the discrepancies among models (Alexander et al., 2017; Prestele et al., 2016).

\subsection{Current approach to providing consistent data: the Land-Use Harmonization (LUH) project}

Large efforts have been undertaken to connect the different sources of land-use data and provide consistent time series for climate modeling applications during the fifth phase of the Coupled Model Intercomparison Project (CMIP5; Taylor et al., 2012) by the LUH project (Hurtt et al., 2011). The resulting dataset (hereafter referred to as LUH data) is commonly used in modeling studies dealing with land use-climate interactions and feedbacks. It has recently been updated for the upcoming sixth phase of the Coupled Model Intercomparison Project (CMIP6; Eyring et al., 2016; Lawrence et al., 2016) and data for the historical period have been published (hereafter referred to as LUH2). Due to the

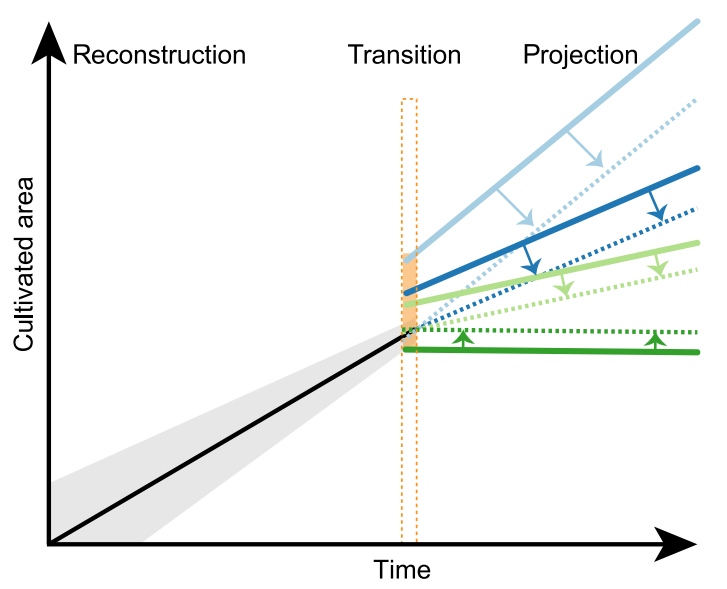

Figure 1. Simplified scheme of the harmonization process. Future projections from different models (solid colored lines) are smoothly connected (dashed colored lines) to the HYDE historical reconstruction (black line; grey shading represents the uncertainty range of LULCC history). Uncertainty about the extent and pattern of current land use and land cover (orange shading) is removed and the total area of cultivated land projected by the different models is changed.

lack of comprehensive documentation of the updated version at the time this paper was written and as, to our best knowledge, the points we demonstrate using LUH will still be valid with the new product, we primarily refer to the CMIP5 version in the remainder of this paper.

Hurtt et al. (2011) extended their Global Land-use Model (GLM; Hurtt et al., 2006) to produce a consistent time series of land-use states (fraction of each land-use category in a grid cell) and transitions (changes between land-use categories in a grid cell) for the time period 1500-2100. The cropland, pasture, and wood harvest projections of four IAMs were smoothly connected to the History Database of the Global Environment (HYDE) historical reconstruction of agricultural land use (Klein Goldewijk et al., 2011) and historical wood harvest estimates by applying the decadal spatial patterns from the projections onto the HYDE map of 2005 (Fig. 1). This harmonization process tries to conserve the original patterns, rate, and location of change as much as possible and to reduce the differences between the models due to definition of cropland, pasture, and wood harvest. To achieve the final harmonized time series and explicit transitions, the preprocessed land-use time series are used as input into the GLM model and constrained by further data and assumptions about the occurrence of shifting cultivation, the spatial pattern of wood harvest, priority of the source of agricultural land, and biomass density (Hurtt et al., 2011). The harmonization ensured, for the first time, consistent land-use input for climate model intercomparisons and thus facilitated the implementation of anthropogenic impact on the land in climate models. Beyond this inarguable success, several uncertainties are to date not, or only partially, addressed in the 
LUH data. In the following section we discuss the main uncertainties and how they may propagate into TBMs, impacting the amplitude and possibly even the sign of land-use interactions and feedbacks.

\subsection{Open issues in the LUH data and their implications for climate change assessments}

The first major uncertainty of the LUH data evolves from the exclusive consideration of the HYDE baseline dataset for the historical period. The HYDE reconstruction is erroneously regarded as observational data rather than as model output accompanied by various sources of uncertainty (Klein Goldewijk and Verburg, 2013). Importantly, the LUH2 data will additionally include the HYDE low and high estimates of land use for the historical period (Lawrence et al., 2016). However, alternative spatially explicit reconstructions have been proposed (Kaplan et al., 2010; Pongratz et al., 2008; Ramankutty and Foley, 1999) (see Supplement Sect. S1 and Table S1 for additional information on these reconstructions), and have been shown to differ substantially in terms of both the total cultivated area and spatial pattern over time (Meiyappan and Jain, 2012). These differences originate in the scarcity of historical input data (i.e., mainly population estimates) for historical times, the assumption about the functional relationship between population density and land use (e.g., linear or nonlinear), and the allocation scheme used to distribute regional or national estimates of agricultural land to specific grid cell locations (Klein Goldewijk and Verburg, 2013).

The uncertainty about land-use history has several implications for land use-climate interactions (Brovkin et al., 2004). For instance, Meiyappan et al. (2015) found the difference in cumulative land-use emissions among three historical reconstructions for the 21 st century modeled by one TBM to be about $18 \mathrm{PgC}$ or $\sim 11 \%$ of the mean land-use emission. Another study, using three commonly used net land-use datasets in one TBM, revealed differences of about $20 \mathrm{PgC}$ or $\sim 9 \%$ of the mean land-use emission since 1750 (Bayer et al., 2017). Jain et al. (2013) further found contrasting trends in land-use emissions on a regional scale during the past 3 decades, which originate in different amounts and rates of land-use change in different realizations of historical land use. Furthermore, as biophysical climate impacts of land use are known to be substantial, especially on a regional scale (Alkama and Cescatti, 2016; Pielke et al., 2011; Pitman et al., 2009), an inappropriate representation of the uncertainty about land-use history is likely to affect model outcomes regarding changes in local to regional climate. Using the HYDE reconstruction exclusively implies high confidence about land-use history in many large-scale assessments and comparison studies (Kumar et al., 2013; Le Quéré et al., 2015; Pitman et al., 2009); this confidence is in fact lacking. As a result, important uncertainties are excluded from climate change mitigation and adaptation policies developed based on these studies (Mahmood et al., 2016).

Second, large inconsistencies exist between estimates of present-day land use. The LUH approach does not consider the differences between different data regarding the current state of land use as it connects the future projections exclusively to the HYDE end map (Fig. 1). The present-day starting maps of historical reconstructions and future projections are based on maps derived from the integration of remotely sensed land-cover maps and (sub-)national statistics of land use (e.g., Erb et al., 2007; Fritz et al., 2015; Klein Goldewijk et al., 2011; Ramankutty et al., 2008). The land-cover maps in turn disagree about extent and spatial pattern of agricultural land (Congalton et al., 2014; Fritz et al., 2011) due to both inconsistent definitions of individual land-use and landcover categories (e.g., Sexton et al., 2015) and difficulties in identifying them from the spectral response (Friedl et al., 2010). These differences propagate into the starting maps of the various land-use change models, including the IAMs providing data for the LUH (Prestele et al., 2016). Removing these differences can result in substantial deviations of the seasonal and spatial pattern of surface albedo, net radiation, and partitioning of latent and sensible heat flux (Feddema et al., 2005) and can affect carbon flux estimates proposed by TBMs across spatial scales (Quaife et al., 2008).

Finally, the future projections used in the LUH are provided by different IAMs, whereby each of them represents an individual scenario of the four representative concentration pathways (RCPs) in CMIP5 or the five shared socioeconomic pathways (SSPs) in CMIP6 (O'Neill et al., 2017; van Vuuren et al., 2011). These are referred to as "marker scenarios" in the case of the SSPs. A marker scenario entails the implementation of a SSP by one IAM that was elected to represent the characteristics of the qualitative SSP storyline best, while additional implementations of the same SSP in other IAMs are "non-marker scenarios" (Popp et al., 2017; Riahi et al., 2017). Alternative RCP or SSP implementations were not considered in LUH. Land-use change model intercomparisons and sensitivity studies, however, indicate that the uncertainty range emerging from different assumptions in the models, input data, and spatial configuration substantially impacts the model results (Alexander et al., 2017; Di Vittorio et al., 2016; Schmitz et al., 2014). Due to the large range across model outcomes per scenario, the problems of using marker scenarios from different models are evident. However, no better alternative to this approach seems to be currently available, and representing uncertainty across models is valuable (Popp et al., 2017). Model comparisons further revealed that while land-use change models represent the future development of cropland area more consistently, the representation of pastures and forests (if modeled) is poor. For example, the projections of 11 IAMs and LUCMs show large variations in pasture areas in 2030 for many world regions (Fig. 2, background map; Supplement Sect. S2.1). These projections were based on a wide range of scenarios, and thus 


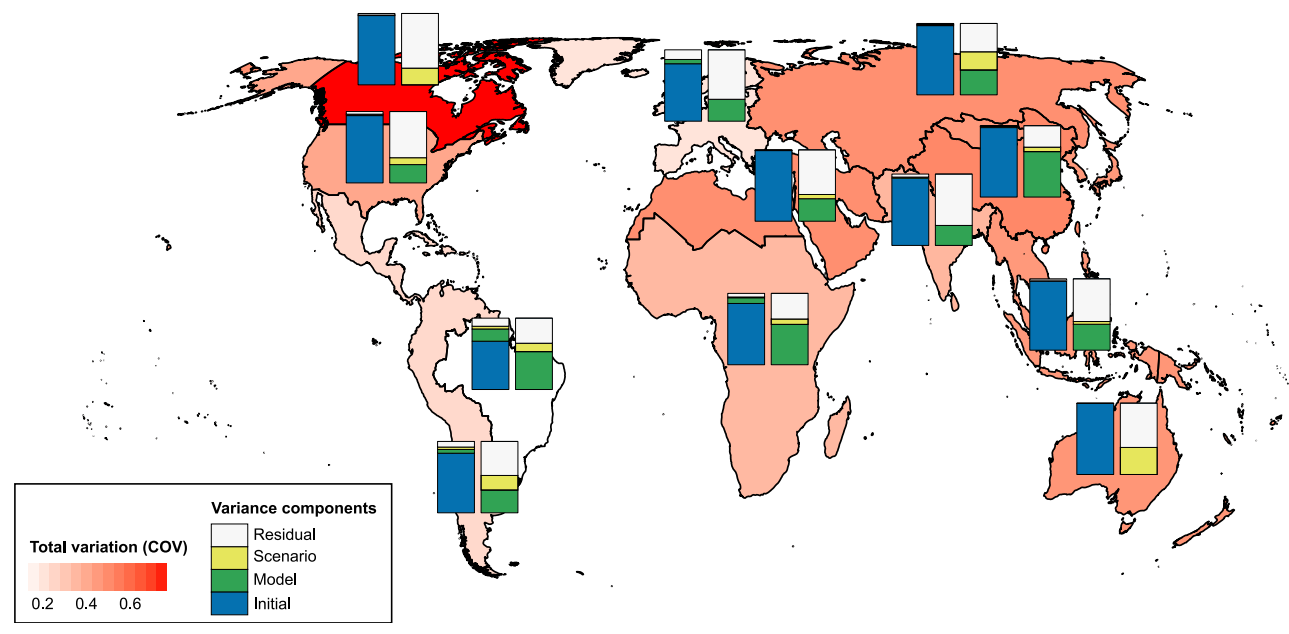

Figure 2. Variation (expressed as coefficients of variation) in pasture projections for 12 world regions in 2030 (shading of the background map). The left bar plots show the relative contribution (as a percentage) of initial variation (pasture area in relation to values reported by FAO (2015) for the year 2010), model-related variation (model type and spatial configuration), and scenario-related variation to the total variation in a region. The right bar plots show the relative contribution (as a percentage) of variance components to the part of total variation that cannot be attributed to initial variation. The figure is based on 11 regional and spatially explicit land-use change models as described in Prestele et al. (2016). Methodological details can be found in Supplement Sect. S2.1 (Table S2) and in Alexander et al. (2017).

variation in outcomes was to be expected (Prestele et al., 2016). The variation attributed to the difference in model structure exceeds the variation due to different scenarios in most regions (Fig. 2, bar plots), while the main part of the variation relates to the different starting points of the models, i.e., deviation from FAO pasture areas in the year 2010. This implies that in many cases the different land-use projections actually do not represent different outcomes resulting from different scenario assumptions, but rather differences between land-use data input used to calibrate the models and the implementation of drivers and processes in the models. Consequently, differences in future climate impacts of land use are likely also affected by the structural differences across land-use change models.

\section{Challenge II: considering gross land-use changes}

\subsection{Background and emergence}

Typically, net land-use changes are applied in TBMs. Net land-use changes refer to the summed grid cell difference in land-use categories between two subsequent time steps at a certain spatial and temporal resolution. Gross change representations provide additional information about land-use changes on a sub-grid scale. The total area in a grid cell that has been affected by change can be calculated by the sum of all individual changes (i.e., area gains and area losses). Gross changes have been shown to be substantially larger than net changes due to bidirectional change processes happening at the same time step (Fuchs et al., 2015a; Hurtt et al., 2011) that are obscured in net change representations. For example, $20 \mathrm{~km}^{2}$ cropland at time $t_{1}$ and $40 \mathrm{~km}^{2}$ at time $t_{2}$ within a grid cell does not necessarily mean that this change resulted from clearing exactly $20 \mathrm{~km}^{2}$ of forest. Equally plausible would be clearance of forest of larger spatial extent, while at the same time also abandoning a certain amount of cropland, resulting in the same net areal change.

Gross changes are not consistently defined across communities. Commonly, shifting cultivation (mostly occurring today in parts of the tropics) and cropland-grassland dynamics (i.e., the bidirectional process of cropland expansion and abandonment) are referred to as gross changes (Fuchs et al., 2015a; Hurtt et al., 2011). Moreover, in the carbon cycle and climate modeling communities, wood harvest (in addition to forest cleared for agricultural land) is sometimes included in gross changes (Hurtt et al., 2011; Stocker et al., 2014; Wilkenskjeld et al., 2014). A more general definition would include all area changes (i.e., gains and losses across all categories represented in a product) that are not depicted in land-use change products (Fuchs et al., 2015a). The larger the averaging unit (be it in terms of grid cell or time), the greater the discrepancy between gross and net changes becomes. Re-gridding of high-resolution (e.g., $5 \mathrm{arcmin}$ ) landuse information to the TBM grid $\left(\sim 0.5^{\circ}\right)$ thus entails additional loss of information on land-use transitions unless gross changes are considered.

These sub-grid dynamics have been shown to be of importance when modeling change of carbon and nutrient stocks in response to land-use change in recent TBM studies (Bayer et al., 2017; Fuchs et al., 2016; Stocker et al., 2014; Wilkenskjeld et al., 2014). For example, Bayer et al. (2017) found the global cumulative land-use carbon emission to be $\sim 33 \%$ higher over the time period 1700-2014. Stocker et al. (2014) 
likewise report increased carbon emissions in recent decades and for all RCPs when accounting for shifting cultivation and wood harvest. Similarly, Wilkenskjeld et al. (2014) found a $60 \%$ increase in the annual land-use emission for the historical period (1850-2005) and a range of 16-34\% increase for future scenarios, when accounting for gross changes. Recently, Arneth et al. (2017) demonstrated uniformly larger historical land-use change carbon emissions across a range of TBMs when shifting cultivation and wood harvest were included, which has implications for understanding of the terrestrial carbon budget as well as for estimates of future carbon mitigation potential in regrowing forest.

Except for such sensitivity studies, gross changes have hardly been considered so far in land use-climate interaction studies (a notable exception being Shevliakova et al., 2013), mainly due to two reasons. First, gross change estimates have not been available until recently. Deriving estimates of historical and future gross change is a difficult task since gross changes vary with spatial and temporal scale (Fuchs et al., 2015a), i.e., they are dependent on the scale of the underlying net change product used for modeling and to what extent gross change processes are included in the individual land-use change models. Second, the implementation of bidirectional changes below the native model grid often entails substantial technical modification to TBM structure, meaning that many TBMs are currently not ready to include information on gross changes or only started recently to include it.

\subsection{Example: gross changes due to re-gridding in the CLUMondo model}

To illustrate the amount of land-use and land-cover change that might be missed in net representations, we conducted an analysis based on the output of a dedicated high-resolution LUCM (CLUMondo; 5 arcmin spatial resolution; Eitelberg et al., 2016; Van Asselen and Verburg, 2013). We tracked all changes between five land-use and land-cover categories (cropland, pasture, forest, urban, and bare) at the original resolution over the time period from 2000 to 2040. Aggregating to ca. $0.5^{\circ}$ resolution allowed the differentiation of the gross area from the net area affected by change (see Supplement Sect. S2.2 for methodological details). The results, shown in Fig. 3, indicate that gross changes are substantially higher than net changes all over the globe, including the temperate zone and high latitudes. It has to be noted that Fig. 3 is only based on one realization of a single LUCM, i.e., not necessarily representing the full extent and spatial pattern of global-scale gross changes. The analysis only depicts the loss of information while re-gridding from 5 arcmin to $0.5^{\circ}$ resolution. Thus, bidirectional changes below the spatial resolution of the original data are still not captured.

\subsection{Current approaches to providing gross change information: LUH and analysis of empirical data}

To provide estimates of gross change, the land-use change modeling community currently follows two different approaches. First, Hurtt et al. (2011), within the framework of LUH, propose a matrix that provides explicit transitions between cropland, pasture, urban, and natural vegetation. Subgrid-scale information is added to net transitions (that are derived from historical or projected land-use data and referred to as "minimum transitions") through assumptions about the extent of shifting cultivation practices and the spatial pattern of wood harvest. In each grid cell, where shifting cultivation appears according to a map of Butler (1980), an average land-abandonment rate is added to each transition from and to agricultural land. In LUH2 an updated shifting-cultivation estimate based on the analysis of Landsat imagery will be included and replace the aforementioned simple assumption (Lawrence et al., 2016). Wood harvest is regarded as gross change, if the wood harvest demand from statistics (historical) or IAMs (future) is not met by deforestation for agricultural land in the net transitions or the GLM model is run in a configuration where deforestation for agricultural land is not counted towards wood harvest demand.

The second approach derives gross / net ratios and a transition matrix directly from empirical data such as historical maps or high-resolution remote sensing products. These ratios can subsequently be applied to existing historical or future net representations to provide estimates of additional area affected by change (Fuchs et al., 2015a).

\subsection{Open issues in the current approaches}

The LUH gross transitions account for some aspects of gross changes. However, the values are dependent on what one includes in the definition of gross changes and are based on overly simplistic assumptions. Most of the gross transitions appear in parts of the tropics, where shifting cultivation is assumed to be an important agricultural practice (Bayer et al., 2017; their Fig. S1). Gross changes outside of these areas are mainly related to wood harvest, i.e., the (additional) area deforested to meet external wood harvest demands. Although these are regarded as gross changes in some literature (e.g., Hurtt et al., 2011; Stocker et al., 2014), we argue that wood harvest not leading to an actual areal change of land cover (e.g., forest to cropland) should be referred to as land management rather than gross change. Excluding wood harvest from the LUH data restricts the occurrence of gross changes to the areas of shifting cultivation. However, our analysis of CLUMondo output (Fig. 3), along with the European analysis of Fuchs et al. (2015a), suggests substantial amounts of gross change (below the $0.5^{\circ} \mathrm{LUH}$ grid) also in the temperate zone and the high latitudes. Consequently, the LUH approach heavily depends on the resolution of the original landuse data (provided by IAMs or historical reconstructions) and 

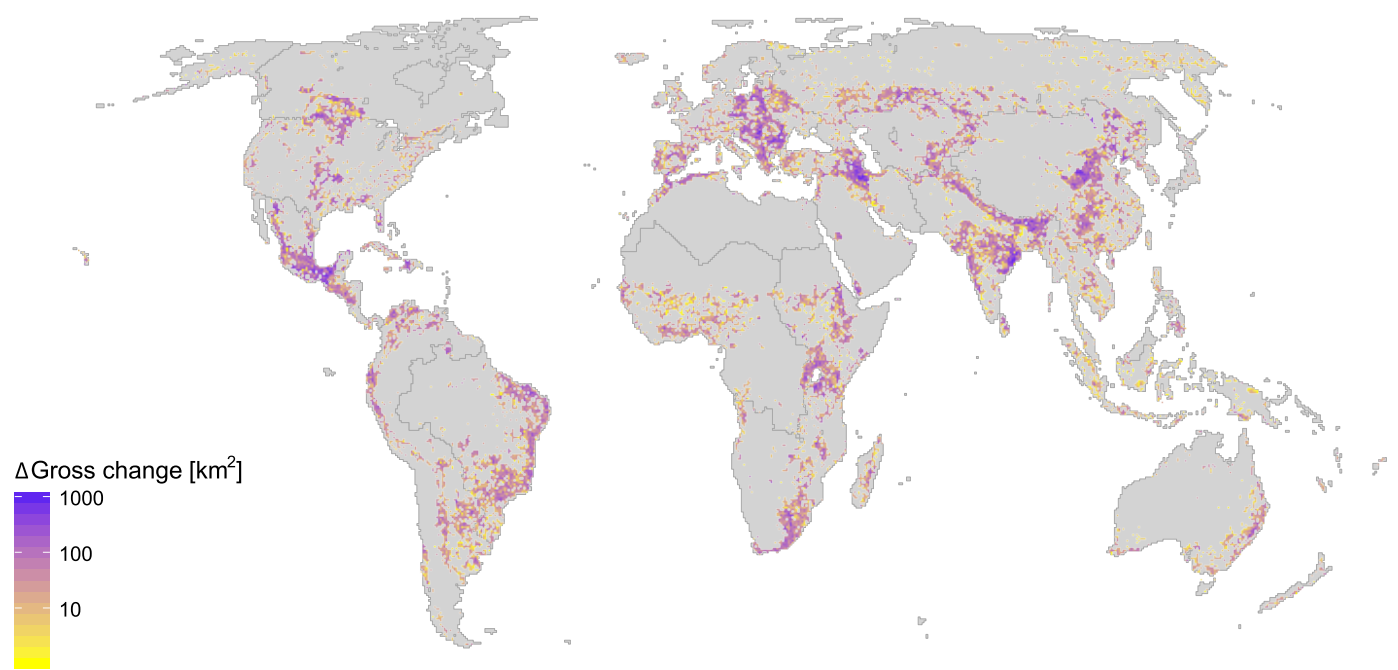

Figure 3. Difference between gross versus net area affected by change at grid cell level (ca. $0.5^{\circ} \times 0.5^{\circ}$ ) as shown by one realization of a single LUCM (CLUMondo; FAO 3 demand scenario). Areas affected by net or gross change have been accumulated over a 40-year simulation period (2000-2040). Net changes are calculated at ca. $0.5^{\circ} \times 0.5^{\circ}$ resolution, while gross changes also account for bidirectional changes at the 5 arcmin native CLUMondo resolution (Supplement Sect. S2.2; Fig. S1). Darker colors indicate a larger difference between the area changed under net and gross change views at ca. $0.5^{\circ} \times 0.5^{\circ}$ grid level. Note the logarithmic scale.

their ability to represent land-use change dynamics on a subgrid scale.

The data-based approach avoids the process uncertainty that hinders high-resolution model projections of land use, but is limited to the time period where empirical data through remote sensing is available. Additional sources such as historical land-use and land-cover maps and statistics (Fuchs et al., 2015b) may contribute to covering longer time periods, although with limited spatiotemporal resolution and spatial coverage, and an associated increase in uncertainty. It is thus difficult to develop multi-century reconstructions or future scenarios including gross changes using data-based approaches since the derived gross / net ratios are only valid for periods of data coverage and are expected to change over time (Fuchs et al., 2015a).

\section{Challenge III: allocation of managed land in TBMs}

\subsection{Background and emergence}

The LSMs in most Earth system models (ESMs) in CMIP5 treated the land surface as a static representation of current land-use and land-cover distribution typically derived from remote sensing products (Brovkin et al., 2013; de NobletDucoudré et al., 2012). DGVMs, some of which are incorporated in the land surface component of ESMs, were originally designed to model potential natural vegetation as a dynamic function of monthly climatology, bioclimatic limits, soil type, and the competitiveness of different wood- or grass-shaped plant functional types (PFTs) (Prentice et al., 2007). Thus, the early TBMs were not able to sufficiently account for anthropogenic activity on the land surface and consequently the impact of land use on climate and biogeochemical cycles (Flato et al., 2013). However, over the last decade, representation of human land-cover change and also some land-management aspects have increasingly been added to these models, albeit with levels of complexity that vary from crops as grassland to more detailed agricultural representations (Bondeau et al., 2007; Le Quéré et al., 2015; Lindeskog et al., 2013). Crop functional types (CFTs) and management options have been introduced in some models, explicitly parameterizing the phenology and biophysical and biogeochemical characteristics of major crop types and distinguishing important management options such as irrigation, fertilizer application, occurrence of multiple cropping, or processing of crop residues (Bondeau et al., 2007; Lindeskog et al., 2013). However, since TBMs do not include representations of human activity as a driver of changes in the land surface, information about the extent and exact location of managed land is required from external data sources such as IAMs or LUCMs.

IAMs and LUCMs usually provide land-cover information (e.g., forest, grassland, and shrubland) along with land-use information (e.g., cropland and pasture). However, as modeling changes in natural vegetation type is one of the primary functions of many TBMs, only land-use information has been used in the LUH (Hurtt et al., 2011). Hence, TBM modelers have to decide in which way the natural vegetation in a grid cell has to be reduced (in case of expansion of managed land) or increased (in case of abandonment of managed land). This has resulted in a range of different strategies, which we show as an illustration in Table 1 for a nonexhaustive list of models. The decision is important as it im- 
Table 1. Examples of allocation rules at grid cell level to implement agricultural land in different TBMs.

\begin{tabular}{llll}
\hline Model & Land use/cover types & Allocation strategy & Reference \\
\hline LPJ-GUESS & natural, cropland, and pasture & proportional reduction & Lindeskog et al. (2013) \\
HadGEM2-JULES & natural (tree, shrub, and grass) cropland, and pasture & grassland first & Clark et al. (2011) \\
ORCHIDEE & natural (tree, grass), cropland, and pasture & proportional reduction & Krinner et al. (2005) \\
LPJ-mL & natural (tree, grass), cropland, and pasture & proportional reduction & Bondeau et al. (2007) \\
\hline
\end{tabular}

pacts the distribution of the natural vegetation in a grid cell, as well as the mean length of time that land has been under a particular use, with consequences for both the biogeochemical and biophysical properties (Reick et al., 2013). For example, new cropland expanding into forest would lead to a large and relatively rapid loss of ecosystem carbon due to deforestation, while cropland expanding into former grassland would have a less immediate impact on ecosystem carbon stocks due to the long time lag (years to centuries) for the resulting changes in soil carbon to be realized (Pugh et al., 2015). Likewise, the albedo and partitioning of energy differs strongly between forest and grassland land covers (Mahmood et al., 2014; Pielke et al., 2011). In the following sections we illustrate, based on literature review and analysis of empirical and modeled data, that the previously described simple allocation algorithms, applied globally within TBMs, do not account well for the spatiotemporal variation in land-use and land-cover change.

\subsection{Spatial heterogeneity of cropland transitions - empirical evidence}

Table 2 summarizes dominant sources of cropland expansion for several world regions and demonstrates the heterogeneity in the spatial pattern of expanding agriculture. For Europe, the CORINE land-cover product (Bossard et al., 2000) indicates over two consecutive time periods (1990-2000, 20002006) shrubland systems to be the main source of expanding agricultural land, followed by low-productivity grasslands and forests (Fig. 4a). In contrast, over a similar time period, the NLCD (Homer et al., 2015) for the USA shows low-productivity grasslands as the dominant source of new croplands, while pastures are predominantly converted from forest or shrubland systems and grasslands only account for around $20 \%$ of new pastures (Fig. 4b). A large-scale study by Graesser et al. (2015) covering Latin America and based on the interpretation of MODIS images for the time period 2001-2013 identified the dominant trajectory of forests being first converted to pastures and subsequently to cropland. They show, however, varying patterns on national and ecoregional scales. This regional variation is also emphasized by Ferreira et al. (2015), who describe a satellite-based transition matrix as input for a modeling study for different states in Brazil. They do not distinguish non-forest natural vegetation such as the Cerrado systems, which might be another im- portant source for agricultural land (Grecchi et al., 2014). A study conducted by Gibbs et al. (2010) investigating agricultural expansion in the tropics in the 1980s and 1990s based on data from the Food and Agriculture Organization of the United Nations (2000) (i.e., areas with less than $10 \%$ forest cover are not considered) concludes that more than $80 \%$ of new agricultural land originates from intact or degraded forests. Gibbs et al. (2010) further found large variability in agricultural sources across seven major tropical regions, e.g., substantially higher conversions from shrublands and woodlands to agricultural land in South America and eastern Africa. Grasslands have been detected as the main source of agricultural land in northern China, e.g., by Li (2008), Liu et al. (2009), and Zuo et al. (2014), while in the Yangtze River basin woodlands contribute most (Wu et al., 2008) (Table 2). All the studies mentioned indeed combine different approaches to derive changes, cover different time periods, and are not representative of current agricultural change hotspots (Lepers et al., 2005). However, this kind of aggregated analysis already indicates that the spatial pattern of agricultural change dynamics varies across world regions and a single global algorithm to replace natural vegetation by managed land in TBMs is likely to be overly simplistic.

\subsection{Example: spatial heterogeneity of cropland transitions in the CLUMondo model}

As it is not possible to compare the land-use allocation strategies of TBMs with historical change data on a global scale due to the lack of accurate global land-use and landcover products (though products with higher resolution (up to $\sim 30 \mathrm{~m}$ ), more frequent temporal coverage, and increasing thematic detail are just emerging; Ban et al., 2015), we additionally tested to what extent cropland expansion simulated by the land-use change model CLUMondo (Eitelberg et al., 2016; Van Asselen and Verburg, 2013) represents one or more of the simplified algorithms currently considered in TBMs (Table 1).

CLUMondo models the spatial distribution of land systems over time, instead of land use and land cover directly. Land systems are characterized by, in addition to other factors, a mosaic of land use and land cover within each grid cell. The land systems are allocated to the grid in each time step "based on local suitability, spatial restrictions, and the competition between land systems driven by demands for 
(a)

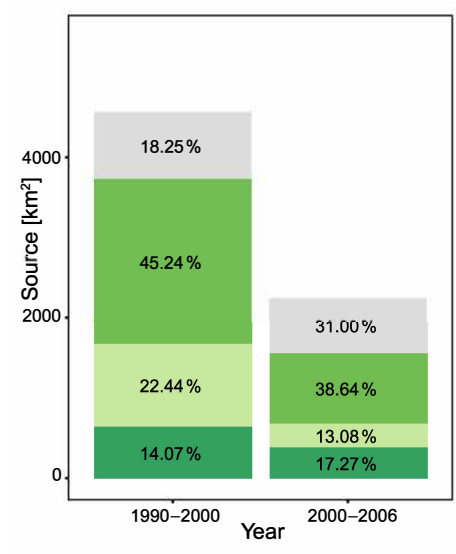

(b)

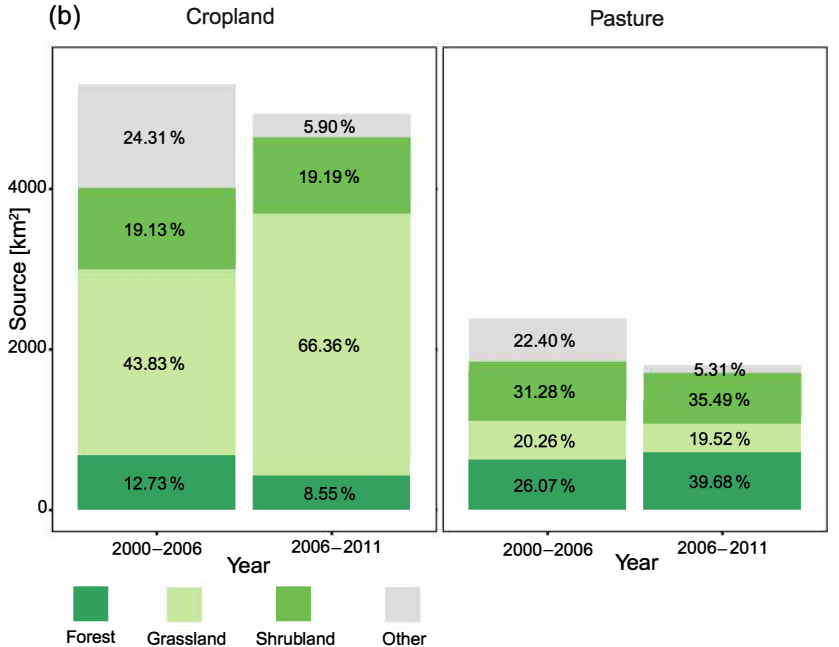

Figure 4. Sources of agricultural land (cropland and pasture combined) for two time periods in Europe based on the CORINE land-cover data (a) and sources of cropland and pasture for two time periods in the USA based on the NLCD land-cover data (b) (Supplement Sect. S2.3, Table S3). Changes between different agricultural classes are not considered as expansion of agricultural land. Aggregation of CORINE and NLCD legends to forest, grassland, and shrubland is according to Tables S4-5. The category "other" includes urban land, wetlands, water, and bare land.

Table 2. Case studies and continental-scale remote sensing studies that report main sources of agricultural expansion or allow for land-cover change detection.

\begin{tabular}{|c|c|c|c|c|}
\hline Region & Temporal coverage & $\begin{array}{l}\text { Main source of new } \\
\text { cropland }\end{array}$ & $\begin{array}{l}\text { Main source of new } \\
\text { pasture }\end{array}$ & Reference \\
\hline \multirow[t]{2}{*}{ Europe } & 1990-2000/ & Shrubland/ & Shrubland/ & \multirow[t]{2}{*}{ Bossard et al. (2000) } \\
\hline & 2000-2006 & Shrubland* & Shrubland* & \\
\hline \multirow[t]{2}{*}{ USA } & 2001-2006/ & Grassland/ & Shrubland/ & \multirow[t]{2}{*}{ Homer et al. (2015) } \\
\hline & 2006-2011 & Grassland & Forest & \\
\hline Latin America & 2001-2013 & Pasture & Forest & Graesser et al. (2015) \\
\hline \multirow[t]{4}{*}{ Northern China } & 1989-1999/ & Grassland/ & - & Li (2008) \\
\hline & 1999-2003 & Grassland & & \\
\hline & $1986-2000$ & Grassland & - & Liu et al. (2009) \\
\hline & $1995-2010$ & Grassland & - & Zuo et al. (2014) \\
\hline Yangtze River basin & $1980-2000$ & Woodland & - & Wu et al. (2008) \\
\hline Brazil & 1994-2002 & Forest & Forest & Ferreira et al. (2015) \\
\hline Tropics & $1980-2000$ & Forest* & Forest* & Gibbs et al. (2010) \\
\hline
\end{tabular}

* Source refers to all new agricultural land, i.e., cropland and pasture combined.

different goods and services" (Eitelberg et al., 2016; Van Asselen and Verburg, 2013). Thus, the determination of the source land use or land cover upon cropland expansion can be interpreted as a complex algorithm taking into account external demands, the land-use distribution of the previous time step, local suitability in a grid cell, and neighborhood effects (i.e., cropland expansion in a grid cell also depends on the availability of suitable land in the surrounding grid cells). This strategy differs from the one in TBMs in a way that not one simple rule is applied to each grid cell equally, but accounts for the spatial heterogeneity of drivers of landuse change.
In order to compare the sources of cropland expansion in CLUMondo to the globally applied rules in TBMs, we reclassified the outputs of the same CLUMondo simulation utilized in Sect. 3.2 (FAO3D; Eitelberg et al.; 2016) according to their dominant land-use or land-cover type to derive transitions (Table S6) and classified the changes within each ca. $0.5^{\circ} \times 0.5^{\circ}$ grid cell as either grassland first, forest first, proportional, or a complex reduction pattern (Table 3; Fig. S2-3 and additional explanation in Supplement Sect. S2.4). Additionally, a grid cell was labeled undefined if grassland or forest was not available in the source map.

Figure 5 shows the results of this analysis for decadal time steps between 2000 and 2040. Based on the CLUMondo 
Table 3. Definition of classified algorithms in the CLUMondo exercise (Sect. 4.3). CLUMondo data were preprocessed as described in the text and Supplement Sect. S2.4. Each ca. $0.5^{\circ} \times 0.5^{\circ}$ grid cell was assigned a label according to the distribution of changes seen in the higher resolution (5 arcmin) CLUMondo data. Land types according to the reclassification of CLUMondo land systems are shown in Table S6; mosaics refer to a mixture of vegetation within a grid cell (e.g., forest and grassland).

\begin{tabular}{|c|c|}
\hline Label & Within a $0.5^{\circ} \times 0.5^{\circ}$ grid cell... \\
\hline Undefined & ...forest or grassland were not available for conversion to cropland.* \\
\hline Unvegetated first & ...urban or bare were converted to cropland, although vegetation was available. \\
\hline Forest first & $\begin{array}{l}\text {..fforest was predominantly converted to cropland, although grassland and mosaics } \\
\text { were available. }\end{array}$ \\
\hline Grassland first & $\begin{array}{l}\text {... grassland was predominantly converted to cropland, although forest and mosaics } \\
\text { were available. }\end{array}$ \\
\hline Proportional & $\begin{array}{l}\text { (1) ... mosaics were predominantly converted to cropland, although forest and grass- } \\
\text { land were available } \\
\text { (2)...forest and grassland were converted proportionally to cropland. }\end{array}$ \\
\hline Complex & $\begin{array}{l}\text { forest, grassland, and mosaics were simultaneously converted without a preference to } \\
\text { one of the classes or proportional reduction. }\end{array}$ \\
\hline
\end{tabular}

data, it is clear that a single simple algorithm does not account for the temporal and spatial heterogeneity of cropland expansion in a detailed land-use change model. The majority of grid cells with substantial cropland expansion $(>10 \%$ of grid cell area) where we could detect an algorithm (i.e., the grid cell was not classified undefined) show a complex reduction pattern of the remaining land-use and land-cover categories, i.e., any algorithm applied to these grid cells in a TBM could be seen as equally good or bad. The remaining grid cells account for only 24-27\% globally. Moreover, the spatial distribution of grid cells that are classified to the same algorithm is very heterogeneous and changes over time. It has to be noted that this analysis builds on only one realization of one LUCM and results may differ if using another data source in terms of overall cropland expansion and the exact grid cell location of changes. However, the analysis does not aim at identifying the exact location of a particular algorithm but rather at emphasizing the heterogeneous pattern of cropland expansion.

\subsection{Current approach to providing allocation information: the transition matrix}

In CMIP5, most ESMs implemented a proportional reduction of natural vegetation rather arbitrarily due to reasons of simplicity or internal model constraints; others converted grassland preferentially and/or treated croplands differently from pastures upon transformation (de Noblet-Ducoudré et al., 2012). However, none of them depict the complex interplay of biophysical and socioeconomic parameters leading to a heterogeneous spatial pattern of land-use change within the coarse grid resolution used in ESMs. As we have shown in the previous sections, empirical evidence and land-use change models suggest that this complexity is poorly represented by simplistic, globally applied algorithms. The efforts of LUH thus included the provision of a transition matrix, i.e., the explicit identification of source and target categories between agricultural land and natural vegetation at the grid cell level. For each annual time step, the exact fraction of a grid cell that has changed from one land-use category to another is determined, thus providing the option to replace the simple allocation options with detailed information about land-use transitions within each grid cell (Hurtt et al., 2011).

\subsection{Open issues of transition matrices}

The provision of transition matrices, however, generally brings up a sequence of additional challenges, which we illustrate using the example of LUH in the following. First, the decision of which land-cover type should be replaced upon cropland or pasture expansion (or introduced in case of abandonment) is in fact only shifted from the TBM community to the IAM/LUCM community and the accuracy of the transitions are heavily dependent on the sophistication (i.e., knowledge about and depiction of land-use change drivers and processes on the grid scale) of the land-use allocation algorithm in the original model providing the land-use data. Many current models simulate land-use changes on a world regional level and downscale these aggregated results to the required grid cell level (Hasegawa et al., 2016; Schmitz et al., 2014). In the LUH approach these downscaled data are used to derive the minimum transitions between agricultural land use and natural vegetation. Additional assumptions are made to allocate changes in land-use states to explicit tran- 

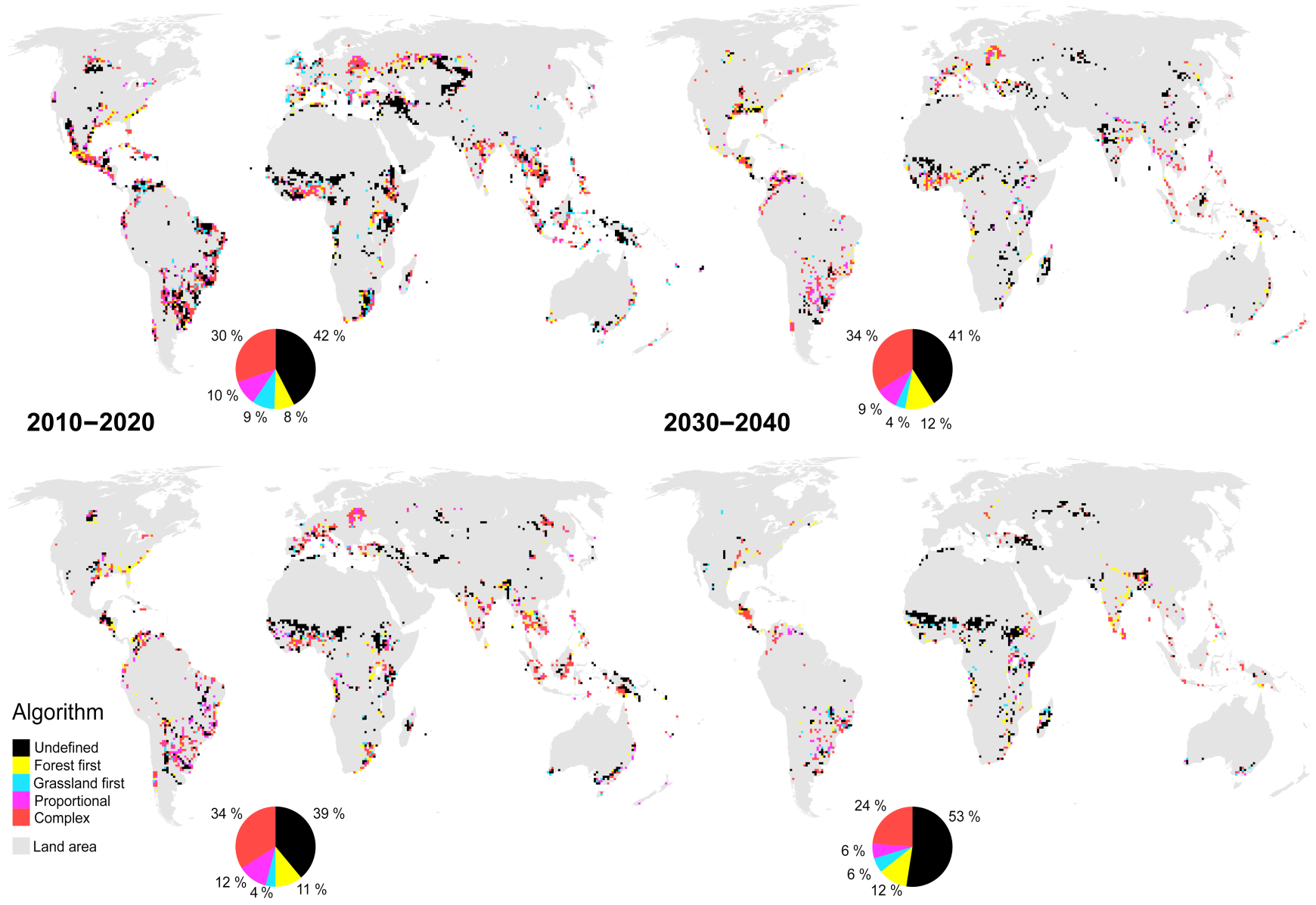

Figure 5. Transitions from natural vegetation to cropland as shown by the CLUMondo model (FAO 3 demand scenario) from 2000 to 2040 in decadal time steps. Colored grid cells represent areas with at least $10 \%$ of cropland expansion within a ca. $0.5^{\circ} \times 0.5^{\circ}$ grid cell. Grid cells are classified according to forest-first (yellow), grassland-first (cyan), proportional (magenta), and complex (red) reduction algorithms as described in the text (for details see Supplement Sect. S2.4). Black grid cells denote areas where the validity of no algorithms could be detected. Grid cells classified as unvegetated first (Table 3 ) are not shown due to a very small contribution $(<0.1 \%)$. Grid cells in this figure have been aggregated to ca. $1.0^{\circ} \times 1.0^{\circ}$ following a majority resampling for reasons of readability. A high-resolution version of the maps, including the full detail of the classification results, can be found in the Supplement (Fig. S4).

sitions, not accounting for the spatial and temporal heterogeneity of the multiple drivers of land-use change. For example, urban expansion is applied proportionally to cropland, pasture, and (secondary) natural vegetation. Upon transitions between natural vegetation and agricultural land, choices in the model configuration have to be made, whether primary or secondary land is converted preferentially. These choices are similar to the grassland- or forest-first reduction algorithms applied in TBMs.

Moreover, due to the lack of empirical long-term, highly accurate land-use and land-cover change information and the inconsistencies between agricultural land-use data and landcover information from satellites, global IAMs and LUCMs are rarely evaluated against independent data (Verburg et al., 2015). It is thus not clear yet to what extent the spatial land-use patterns simulated by these models and provided to LUH represent a good estimate of real past and future landuse changes. In consequence, transitions derived from these modeled time series are uncertain.

Hence, it is evident that more and improved empirical information on land-use transitions is required to improve land-use change modeling and to estimate the natural systems at risk under agricultural expansion. However, the specific problem of allocating new agricultural land in DGVMs and LSMs also has strong model and data-structure components. In many DGVMs, the grass and forest PFTs on nonagricultural land in a grid cell are mostly not considered different systems, but are part of one complex vegetation structure thus not representing spatially horizontal heterogeneity. Therefore, when agriculture expands into such natural sys- 
tems, all natural PFTs need to be reduced proportionally. If handled otherwise (i.e., when removing a specific PFT preferentially), the vegetation dynamics would slowly converge again towards the initial PFT mix (if all boundary conditions like climate and soil properties remain unchanged).

For LSMs coupled to ESMs, the situation is slightly more complex. Most ESMs (if not incorporating dynamic vegetation through a DGVM) use a remote sensing product such as the ESA CCI-LC (ESA, 2014) and a translation to PFTs, e.g., Poulter et al. (2011), as a background vegetation map on which agricultural land is imposed. Due to inaccuracies in global remote sensing land-cover products and differences in historical reconstructions (as discussed in Sect. 2), fractions of agricultural land on a grid scale are subject to differences between the background map and the external land-use dataset. Consequently, the PFT composition outside the prescribed agricultural land can represent either the real heterogeneity in natural vegetation or represent a mix of natural and anthropogenic land cover due to differences in the datasets. However, these cases are difficult to distinguish and empirically justified transition matrices, together with more accurate present-day land-cover products, would provide a useful tool for reducing uncertainties due to allocation decisions in ESMs.

\section{Recommendations for improving the current LULCC representation across models}

\subsection{Tackling uncertainties in the harmonization}

The LUH (Hurtt et al., 2011) has allowed the inclusion of anthropogenic impacts on the land surface for the first time in the CMIP5 climate change assessments. As we have shown in Sect. 2, three major sources of uncertainty, which include the uncertainty about land-use history, inconsistencies in present-day land-use estimates, and structural differences across IAMs and LUCMs, are poorly addressed through the almost exclusive implementation of the LUH dataset within the climate modeling community. A wider range of harmonized time series is therefore likely to substantially influence the outcomes of studies on land use-climate interactions. The actual impact of alternative harmonized time series on carbon cycle (and other ecosystem processes) and climate has never been tested, mainly due to the lack of alternative provision of such products. One would need a multi-model ensemble design to properly account for and disentangle the individual contributions of different historical reconstructions, the multitude of present-day land-use products, and varying future land-use change modeling approaches. Different future scenario models would need to be connected to different instances of historical reconstructions, both constrained by different plausible realizations (i.e., based on previously published, peer-reviewed approaches) of current land use and land cover. Such an approach would ensure a comprehensive coverage of the uncertainties accumulating across temporal and spatial scales prior to feeding land-use data into climate models and allow for testing of climate model sensitivity to different realizations of land-cover and land-use information.

The high computational demands of complex ESMs probably do not allow for multiple runs including all the uncertainties in land-use forcing. However, to derive robust results from climate model intercomparisons, a sufficient quantification of uncertainty in the land-use forcing dataset is urgently required. If this proves impractical through ESM simulations, we recommend utilizing less computationally expensive models such as DGVMs and offline LSMs to assess the full range of uncertainty and to determine a limited set of simulations, which appears to significantly affect biogeochemical cycles and climate. These can be subsequently used to test the uncertainty range in ESMs.

Simultaneously, we suggest that the land-use and remotesensing communities should engage to reduce uncertainties in land-use and land-cover products by

1. developing diagnostics for the evaluation of land-use reconstructions based on satellite data and additional proxy data such as pollen reconstructions (Gaillard et al., 2010) or archeological evidence of early land use (Kaplan et al., 2016);

2. developing systematic approaches to evaluating results of land-use change models against independent data sources, utilizing the full range of high-resolution satellite data (e.g., the Landsat archive and the European Sentinel satellites), reference data obtained from (sub)national reporting schemes under international policy frameworks (e.g., Kohl et al., 2015), and innovative methods such as volunteered geographic information and crowdsourcing (Fritz et al., 2012). Although satellite data are also not directly measured empirical data, but go through a mathematical conversion process prior to a final land-cover product, they can improve representations of present-day land cover. If not yet possible on the global scale due to the limitations discussed in Sect. 2, we recommend the implementation of regionalscale evaluation schemes using smaller-scale, highly accurate remote sensing products as a starting point for later integration into global applications.

\subsection{Gross change representations}

The full extent of gross changes is still not well understood (see Sect. 3). Thus, the land-use community should explore high-resolution remote-sensing imagery regarding their ability to derive gross change estimates and improve understanding of sub-grid dynamics, which are not yet captured by their models. Regions where driving factors of small-scale landuse change processes are more complex and not easy to determine due to frequent land-use changes should receive special attention. Based on such analyses, multi-century reconstructions and projections for climate and ecosystem assess- 
ments could be enhanced for at least the satellite era. As models extend further into the past, the detailed information could be gradually replaced by model assumptions, supported by additional reference data such as historical maps and statistics.

\subsection{Transition matrix from empirical data}

Explicit information of land-use transitions instead of annual land-use states is essential for questions regarding carbon and nutrient cycling. We argue that simple, globally applied assumptions about these transitions or the shift of the responsibility from TBMs to land-use models may not solve the problem (Sect. 4). Thus, the development of dedicated transition matrices increasingly based on empirical data (as soon as new products emerge) and sophisticated land-use change allocation models, which account for the spatiotemporal heterogeneity of land-use change drivers, is essential.

Simultaneously, TBMs must ensure the use of the full detail of information provided by the implementation of explicit transition information in their land modules. Due to internal model structure, proportional reduction of PFTs needs to be applied in models with internally simulated dynamic vegetation. However, we recommend the utilization of explicit transition information to further evaluate discrepancies between the potential natural vegetation scheme and LULCC data provided by LUCMs and IAMs.

\section{Outlook: towards model integration across disciplines}

The ways forward listed in the previous section will only be the first stage of a process towards improved LULCC representation in climate change assessments. Rather than improving de-coupled data products and models on an individual basis and connecting them offline through the exchange of files, we argue that land use, land cover, and the climate system need to be studied in an integrated modeling framework. As we have shown in this paper, most of the challenges and related uncertainties originate in the disparate disciplinary treatment of the individual aspects. Although sophisticated models have been developed during the past decades within each community, the current offline coupling seems overly limited, accumulating an increasing level of uncertainty along the modeling chain. Integration of these different types of models, where anthropogenic activity on the land system is considered as an integral part of ESMs, instead of an external boundary condition, might help to reduce these uncertainties, although it will certainly further complicate the interpretation of model responses. For example, Di Vittorio et al. (2014) report preliminary results of the iESM (Collins et al., 2015), an advanced coupling of an IAM and an ESM implementing two-way feedbacks between the human and environmental systems, and show how this improved coupling can increase the accuracy of infor- mation exchange between the individual model components. In the long term, additionally including behavioral land system models (e.g., agent-based approaches) in the coupling may provide further understanding of possible land-climatesociety feedbacks (Arneth et al., 2014; Verburg et al., 2015) since the current modeling chain rarely accounts for the complexity of human-environmental relationships and feedbacks (Rounsevell et al., 2014).

Data availability. The illustrative analysis in Sects. 3 and 4 is based on CLUMondo simulations (Eitelberg et al., 2016). CLUMondo source code and simulation results are available from http: //www.environmentalgeography.nl/site/data-models/.

\section{The Supplement related to this article is available online at doi:10.5194/esd-8-369-2017-supplement.}

Competing interests. The authors declare that they have no conflict of interest.

Acknowledgements. The research in this paper has been supported by the European Research Council under the European Union's Seventh Framework Programme project LUC4C (grant no. 603542), ERC grant GLOLAND (no. 311819), and BiodivERsA project TALE (no. 832.14.006) funded by the Dutch National Science Foundation (NWO). This research contributes to the Global Land Programme (www.glp.earth). This is paper number 26 of the Birmingham Institute of Forest Research.

Edited by: R. A. P. Perdigão

Reviewed by: J. Hall and two anonymous referees

\section{References}

Alexander, P., Prestele, R., Verburg, P. H., Arneth, A., Baranzelli, C., Batista e Silva, F., Brown, C., Butler, A., Calvin, K., Dendoncker, N., Doelman, J. C., Dunford, R., Engström, K., Eitelberg, D., Fujimori, S., Harrison, P. A., Hasegawa, T., Havlik, P., Holzhauer, S., Humpenöder, F., Jacobs-Crisioni, C., Jain, A. K., Krisztin, T., Kyle, P., Lavalle, C., Lenton, T., Liu, J., Meiyappan, P., Popp, A., Powell, T., Sands, R. D., Schaldach, R., Stehfest, E., Steinbuks, J., Tabeau, A., van Meijl, H., Wise, M. A., and Rounsevell, M. D. A.: Assessing uncertainties in land cover projections, Glob. Chang. Biol., 23, 767-781, doi:10.1111/gcb.13447, 2017.

Alkama, R. and Cescatti, A.: Biophysical climate impacts of recent changes in global forest cover, Science, 351, 600-604, 2016.

Arneth, A., Harrison, S. P., Zaehle, S., Tsigaridis, K., Menon, S., Bartlein, P. J., Feichter, J., Korhola, A., Kulmala, M., O’Donnell, D., Schurgers, G., Sorvari, S., and Vesala, T.: Terrestrial biogeochemical feedbacks in the climate system, Nat. Geosci., 3, 525532, 2010. 
Arneth, A., Brown, C., and Rounsevell, M. D. A.: Global models of human decision-making for land-based mitigation and adaptation assessment, Nature Climate Change, 4, 550-557, 2014.

Arneth, A., Sitch, S., Pongratz, J., Stocker, B. D., Ciais, P., Poulter, B., Bayer, A. D., Bondeau, A., Calle, L., Chini, L. P., Gasser, T., Fader, M., Friedlingstein, P., Kato, E., Li, W., Lindeskog, M., Nabel, J. E. M. S., Pugh, T. A. M., Robertson, E., Viovy, N., Yue, C., and Zaehle, S.: Historical carbon dioxide emissions caused by land-use changes are possibly larger than assumed, Nat. Geosci., 10, 79-84, 2017.

Ballantyne, A. P., Andres, R., Houghton, R., Stocker, B. D., Wanninkhof, R., Anderegg, W., Cooper, L. A., DeGrandpre, M., Tans, P. P., Miller, J. B., Alden, C., and White, J. W. C.: Audit of the global carbon budget: estimate errors and their impact on uptake uncertainty, Biogeosciences, 12, 2565-2584, doi:10.5194/bg-122565-2015, 2015.

Ban, Y. F., Gong, P., and Gini, C.: Global land cover mapping using Earth observation satellite data: Recent progresses and challenges, Isprs J. Photogramm., 103, 1-6, 2015.

Bayer, A. D., Lindeskog, M., Pugh, T. A. M., Anthoni, P. M., Fuchs, R., and Arneth, A.: Uncertainties in the land-use flux resulting from land-use change reconstructions and gross land transitions, Earth Syst. Dynam., 8, 91-111, doi:10.5194/esd-8-912017, 2017.

Bondeau, A., Smith, P. C., Zaehle, S., Schaphoff, S., Lucht, W., Cramer, W., Gerten, D., Lotze-Campen, H., Muller, C., Reichstein, M., and Smith, B.: Modelling the role of agriculture for the 20th century global terrestrial carbon balance, Glob. Change Biol., 13, 679-706, 2007.

Bossard, M., Feranec, J., and Otahel, J.: CORINE land cover technical guide - Addendum 2000, Technical Report, 40, 2000.

Brovkin, V., Sitch, S., von Bloh, W., Claussen, M., Bauer, E., and Cramer, W.: Role of land cover changes for atmospheric $\mathrm{CO}_{2}$ increase and climate change during the last 150 years, Glob. Change Biol., 10, 1253-1266, 2004.

Brovkin, V., Boysen, L., Arora, V. K., Boisier, J. P., Cadule, P., Chini, L., Claussen, M., Friedlingstein, P., Gayler, V., van den Hurk, B. J. J. M., Hurtt, G. C., Jones, C. D., Kato, E., de NobletDucoudre, N., Pacifico, F., Pongratz, J., and Weiss, M.: Effect of Anthropogenic Land-Use and Land-Cover Changes on Climate and Land Carbon Storage in CMIP5 Projections for the TwentyFirst Century, J. Climate, 26, 6859-6881, 2013.

Butler, J. H.: Economic Geography: Spatial and Environmental Aspects of Economic Activity, John Wiley, New York, 1980.

Canadell, J. G., Le Quéré, C., Raupach, M. R., Field, C. B., Buitenhuis, E. T., Ciais, P., Conway, T. J., Gillett, N. P., Houghton, R. A., and Marland, G.: Contributions to accelerating atmospheric $\mathrm{CO}_{2}$ growth from economic activity, carbon intensity, and efficiency of natural sinks, P. Natl. Acad. Sci. USA, 104, 1886618870, doi:10.1073/pnas.0702737104, 2007.

Clark, D. B., Mercado, L. M., Sitch, S., Jones, C. D., Gedney, N., Best, M. J., Pryor, M., Rooney, G. G., Essery, R. L. H., Blyth, E., Boucher, O., Harding, R. J., Huntingford, C., and Cox, P. M.: The Joint UK Land Environment Simulator (JULES), model description - Part 2: Carbon fluxes and vegetation dynamics, Geosci. Model Dev., 4, 701-722, doi:10.5194/gmd-4-701-2011, 2011.

Collins, W. D., Craig, A. P., Truesdale, J. E., Di Vittorio, A. V., Jones, A. D., Bond-Lamberty, B., Calvin, K. V., Edmonds, J. A., Kim, S. H., Thomson, A. M., Patel, P., Zhou, Y., Mao, J.,
Shi, X., Thornton, P. E., Chini, L. P., and Hurtt, G. C.: The integrated Earth system model version 1: formulation and functionality, Geosci. Model Dev., 8, 2203-2219, doi:10.5194/gmd8-2203-2015, 2015.

Congalton, R. G., Gu, J. Y., Yadav, K., Thenkabail, P., and Ozdogan, M.: Global Land Cover Mapping: A Review and Uncertainty Analysis, Remote Sensing, 6, 12070-12093, 2014.

Davidson, E. A.: The contribution of manure and fertilizer nitrogen to atmospheric nitrous oxide since 1860, Nat. Geosci., 2, 659662, 2009.

de Noblet-Ducoudré, N., Boisier, J. P., Pitman, A., Bonan, G. B., Brovkin, V., Cruz, F., Delire, C., Gayler, V., van den Hurk, B. J. J. M., Lawrence, P. J., van der Molen, M. K., Muller, C., Reick, C. H., Strengers, B. J., and Voldoire, A.: Determining Robust Impacts of Land-Use-Induced Land Cover Changes on Surface Climate over North America and Eurasia: Results from the First Set of LUCID Experiments, J. Climate, 25, 3261-3281, 2012.

Di Vittorio, A. V., Chini, L. P., Bond-Lamberty, B., Mao, J., Shi, X., Truesdale, J., Craig, A., Calvin, K., Jones, A., Collins, W. D., Edmonds, J., Hurtt, G. C., Thornton, P., and Thomson, A.: From land use to land cover: restoring the afforestation signal in a coupled integrated assessment-earth system model and the implications for CMIP5 RCP simulations, Biogeosciences, 11, 6435-6450, doi:10.5194/bg-11-6435-2014, 2014.

Di Vittorio, A. V., Kyle, P., and Collins, W. D.: What are the effects of Agro-Ecological Zones and land use region boundaries on land resource projection using the Global Change Assessment Model?, Environ. Modell. Softw., 85, 246-265, doi:10.1016/j.envsoft.2016.08.016, 2016.

Eitelberg, D. A., van Vliet, J., Doelman, J. C., Stehfest, E., and Verburg, P. H.: Demand for biodiversity protection and carbon storage as drivers of global land change scenarios, Global Environ. Chang., 40, 101-111, doi:10.1016/j.gloenvcha.2016.06.014, 2016 (data available at: http://www.environmentalgeography.nl/ site/data-models/).

Ellis, E. C.: Anthropogenic transformation of the terrestrial biosphere, Philos. T. R. Soc. A, 369, 1010-1035, 2011.

Ellis, E. C., Kaplan, J. O., Fuller, D. Q., Vavrus, S., Goldewijk, K. K., and Verburg, P. H.: Used planet: A global history, P. Natl. Acad. Sci. USA, 110, 7978-7985, 2013.

Erb, K.-H., Gaube, V., Krausmann, F., Plutzar, C., Bondeau, A., and Haberl, H.: A comprehensive global $5 \mathrm{~min}$ resolution land-use data set for the year 2000 consistent with national census data, Journal of Land Use Science, 2, 191-224, 2007.

ESA: Land Cover CCI Product User Guide version 2.4, European Space Agency, 2014.

Eyring, V., Bony, S., Meehl, G. A., Senior, C. A., Stevens, B., Stouffer, R. J., and Taylor, K. E.: Overview of the Coupled Model Intercomparison Project Phase 6 (CMIP6) experimental design and organization, Geosci. Model Dev., 9, 1937-1958, doi:10.5194/gmd-9-1937-2016, 2016.

FAO (Food and Agriculture Organization of the United Nations): FAOSTAT Database, Resources/Land, Rome, available at: www. fao.org/faostat, last access: 17 October 2015.

Feddema, J., Oleson, K., Bonan, G., Mearns, L., Washington, W., Meehl, G., and Nychka, D.: A comparison of a GCM response to historical anthropogenic land cover change and model sensitivity to uncertainty in present-day land cover representations, Clim. Dynam., 25, 581-609, 2005. 
Ferreira, J. B. D., Ribera, L., and Horridge, M.: Deforestation Control and Agricultural Supply in Brazil, Am. J. Agr. Econ., 97, 589-601, 2015.

Fisher, J. B., Huntzinger, D. N., Schwalm, C. R., and Sitch, S.: Modeling the Terrestrial Biosphere, Annu. Rev. Env. Resour., 39, 91123,2014

Flato, G., Marotzke, J., Abiodun, B., Braconnot, P., Chou, S. C., Collins, W., Cox, P., Driouech, F., Emori, S., Eyring, V., Forest, C., Gleckler, P., Guilyardi, E., Jakob, C., Kattsov, V., Reason, C., and Rummukainen, M.: Evaluation of Climate Models, in: Climate Change 2013: The Physical Science Basis, Contribution of Working Group I to the Fifth Assessment Report of the Intergovernmental Panel on Climate Change, edited by: Stocker, T. F., Qin, D., Plattner, G.-K., Tignor, M., Allen, S. K., Boschung, J., Nauels, A., Xia, Y., Bex, V., and Midgley, P. M., Cambridge University Press, Cambridge, United Kingdom and New York, NY, USA, 2013.

Food and Agriculture Organization of the United Nations: Global Forest Resources Assessment 2000, Rome, 2000.

Friedl, M. A., Sulla-Menashe, D., Tan, B., Schneider, A., Ramankutty, N., Sibley, A., and Huang, X. M.: MODIS Collection 5 global land cover: Algorithm refinements and characterization of new datasets, Remote Sens. Environ., 114, 168-182, 2010.

Fritz, S., See, L., McCallum, I., Schill, C., Obersteiner, M., van der Velde, M., Boettcher, H., Havlík, P., and Achard, F.: Highlighting continued uncertainty in global land cover maps for the user community, Environ. Res. Lett., 6, 44005, doi:10.1088/17489326/6/4/044005, 2011.

Fritz, S., McCallum, I., Schill, C., Perger, C., See, L., Schepaschenko, D., van der Velde, M., Kraxner, F., and Obersteiner, M.: Geo-Wiki: An online platform for improving global land cover, Environ. Modell. Softw., 31, 110-123, 2012.

Fritz, S., See, L., McCallum, I., You, L., Bun, A., Moltchanova, E., Duerauer, M., Albrecht, F., Schill, C., Perger, C., Havlik, P., Mosnier, A., Thornton, P., Wood-Sichra, U., Herrero, M., Becker-Reshef, I., Justice, C., Hansen, M., Gong, P., Abdel Aziz, S., Cipriani, A., Cumani, R., Cecchi, G., Conchedda, G., Ferreira, S., Gomez, A., Haffani, M., Kayitakire, F., Malanding, J., Mueller, R., Newby, T., Nonguierma, A., Olusegun, A., Ortner, S., Rajak, D. R., Rocha, J., Schepaschenko, D., Schepaschenko, M., Terekhov, A., Tiangwa, A., Vancutsem, C., Vintrou, E., Wenbin, W., van der Velde, M., Dunwoody, A., Kraxner, F., and Obersteiner, M.: Mapping global cropland and field size, Glob. Change Biol., 21, 1980-1992, 2015.

Fuchs, R., Herold, M., Verburg, P. H., Clevers, J. G. P. W., and Eberle, J.: Gross changes in reconstructions of historic land cover/use for Europe between 1900 and 2010, Glob. Change Biol., 21, 299-313, 2015a.

Fuchs, R., Verburg, P. H., Clevers, J. G. P. W., and Herold, M.: The potential of old maps and encyclopaedias for reconstructing historic European land cover/use change, Appl. Geogr., 59, 43-55, 2015b.

Fuchs, R., Schulp, C. J. E., Hengeveld, G. M., Verburg, P. H., Clevers, J. G. P. W., Schelhaas, M. J., and Herold, M.: Assessing the influence of historic net and gross land changes on the carbon fluxes of Europe, Glob. Chang. Biol., 22, 2526-2539, doi:10.1111/gcb.13191, 2016.

Gaillard, M.-J., Sugita, S., Mazier, F., Trondman, A.-K., Broström, A., Hickler, T., Kaplan, J. O., Kjellström, E., Kokfelt, U., Kuneš,
P., Lemmen, C., Miller, P., Olofsson, J., Poska, A., Rundgren, M., Smith, B., Strandberg, G., Fyfe, R., Nielsen, A. B., Alenius, T., Balakauskas, L., Barnekow, L., Birks, H. J. B., Bjune, A., Björkman, L., Giesecke, T., Hjelle, K., Kalnina, L., Kangur, M., van der Knaap, W. O., Koff, T., Lagerås, P., Latalowa, M., Leydet, M., Lechterbeck, J., Lindbladh, M., Odgaard, B., Peglar, S., Segerström, U., von Stedingk, H., and Seppä, H.: Holocene land-cover reconstructions for studies on land coverclimate feedbacks, Clim. Past, 6, 483-499, doi:10.5194/cp-6483-2010, 2010.

Gibbs, H. K., Ruesch, A. S., Achard, F., Clayton, M. K., Holmgren, P., Ramankutty, N., and Foley, J. A.: Tropical forests were the primary sources of new agricultural land in the 1980s and 1990s, P. Natl. Acad. Sci. USA, 107, 16732-16737, 2010.

Graesser, J., Aide, T. M., Grau, H. R., and Ramankutty, N.: Cropland/pastureland dynamics and the slowdown of deforestation in Latin America, Environ. Res. Lett., 10, 34017, doi:10.1088/1748-9326/10/3/034017, 2015.

Grecchi, R. C., Gwyn, Q. H. J., Bénié, G. B., Formaggio, A. R., and Fahl, F. C.: Land use and land cover changes in the Brazilian Cerrado: A multidisciplinary approach to assess the impacts of agricultural expansion, Appl. Geogr., 55, 300-312, 2014.

Hanjra, M. A. and Qureshi, M. E.: Global water crisis and future food security in an era of climate change, Food Policy, 35, 365377, 2010.

Hasegawa, T., Fujimori, S., Ito, A., Takahashi, K., and Masui, T.: Global land-use allocation model linked to an integrated assessment model, Sci. Total Environ., 580, 787-796, doi:10.1016/j.scitotenv.2016.12.025, 2016.

Hibbard, K., Janetos, A., van Vuuren, D. P., Pongratz, J., Rose, S. K., Betts, R., Herold, M., and Feddema, J. J.: Research priorities in land use and land-cover change for the Earth system and integrated assessment modelling, Int. J. Climatol., 30, 2118-2128, 2010.

Homer, C., Dewitz, J., Yang, L. M., Jin, S., Danielson, P., Xian, G., Coulston, J., Herold, N., Wickham, J., and Megown, K.: Completion of the 2011 National Land Cover Database for the Conterminous United States - Representing a Decade of Land Cover Change Information, Photogramm. Eng. Rem. S, 81, 345-354, 2015.

Houghton, R. A., House, J. I., Pongratz, J., van der Werf, G. R., DeFries, R. S., Hansen, M. C., Le Quéré, C., and Ramankutty, N.: Carbon emissions from land use and land-cover change, Biogeosciences, 9, 5125-5142, doi:10.5194/bg-9-5125-2012, 2012.

Hurtt, G. C., Frolking, S., Fearon, M. G., Moore, B., Shevliakova, E., Malyshev, S., Pacala, S. W., and Houghton, R. A.: The underpinnings of land-use history: three centuries of global gridded land-use transitions, wood-harvest activity, and resulting secondary lands, Glob. Change Biol., 12, 1208-1229, 2006.

Hurtt, G. C., Chini, L. P., Frolking, S., Betts, R. A., Feddema, J., Fischer, G., Fisk, J. P., Hibbard, K., Houghton, R. A., Janetos, A., Jones, C. D., Kindermann, G., Kinoshita, T., Goldewijk, K. K., Riahi, K., Shevliakova, E., Smith, S., Stehfest, E., Thomson, A., Thornton, P., van Vuuren, D. P., and Wang, Y. P.: Harmonization of land-use scenarios for the period 1500-2100: 600 years of global gridded annual land-use transitions, wood harvest, and resulting secondary lands, Climatic Change, 109, 117-161, 2011.

Jain, A. K., Meiyappan, P., Song, Y., and House, J. I.: $\mathrm{CO}_{2}$ emissions from land-use change affected more by nitrogen cycle, than 
by the choice of land-cover data, Glob. Change Biol., 19, 28932906, 2013.

Jones, C., Robertson, E., Arora, V., Friedlingstein, P., Shevliakova, E., Bopp, L., Brovkin, V., Hajima, T., Kato, E., Kawamiya, M., Liddicoat, S., Lindsay, K., Reick, C. H., Roelandt, C., Segschneider, J., and Tjiputra, J.: Twenty-First-Century Compatible $\mathrm{CO}_{2}$ Emissions and Airborne Fraction Simulated by CMIP5 Earth System Models under Four Representative Concentration Pathways, J. Climate, 26, 4398-4413, 2013.

Kaplan, J. O., Krumhardt, K. M., Ellis, E. C., Ruddiman, W. F., Lemmen, C., and Goldewijk, K. K.: Holocene carbon emissions as a result of anthropogenic land cover change, The Holocene, 21, 775-791, 2010.

Kaplan, J. O., Pfeiffer, M., Kolen, J. C. A., and Davis, B. A. S.: Large Scale Anthropogenic Reduction of Forest Cover in Last Glacial Maximum Europe, PLoS One, 11, e0166726, doi:10.1371/journal.pone.0166726, 2016.

Klein Goldewijk, K. and Verburg, P. H.: Uncertainties in globalscale reconstructions of historical land use: an illustration using the HYDE data set, Landscape Ecol., 28, 861-877, 2013.

Klein Goldewijk, K., Beusen, A., van Drecht, G., and de Vos, M.: The HYDE 3.1 spatially explicit database of human-induced global land-use change over the past 12,000 years, Global Ecol. Biogeogr., 20, 73-86, 2011.

Kohl, M., Lasco, R., Cifuentes, M., Jonsson, O., Korhonen, K. T., Mundhenk, P., Navar, J. D., and Stinson, G.: Changes in forest production, biomass and carbon: Results from the 2015 UN FAO Global Forest Resource Assessment, Forest Ecol. Manag., 352, 21-34, 2015.

Krinner, G., Viovy, N., de Noblet-Ducoudré, N., Ogée, J., Polcher, J., Friedlingstein, P., Ciais, P., Sitch, S., and Prentice, I. C.: A dynamic global vegetation model for studies of the coupled atmosphere-biosphere system, Global Biogeochem. Cy., 19, 133, doi:10.1029/2003GB002199, 2005.

Kumar, S., Dirmeyer, P. A., Merwade, V., DelSole, T., Adams, J. M., and Niyogi, D.: Land use/cover change impacts in CMIP5 climate simulations: A new methodology and 21st century challenges, J. Geophys. Res.-Atmos., 118, 6337-6353, 2013.

Lawrence, D. M., Hurtt, G. C., Arneth, A., Brovkin, V., Calvin, K. V., Jones, A. D., Jones, C. D., Lawrence, P. J., de NobletDucoudré, N., Pongratz, J., Seneviratne, S. I., and Shevliakova, E.: The Land Use Model Intercomparison Project (LUMIP) contribution to CMIP6: rationale and experimental design, Geosci. Model Dev., 9, 2973-2998, doi:10.5194/gmd-9-29732016, 2016.

Le Quéré, C., Moriarty, R., Andrew, R. M., Canadell, J. G., Sitch, S., Korsbakken, J. I., Friedlingstein, P., Peters, G. P., Andres, R. J., Boden, T. A., Houghton, R. A., House, J. I., Keeling, R. F., Tans, P., Arneth, A., Bakker, D. C. E., Barbero, L., Bopp, L., Chang, J., Chevallier, F., Chini, L. P., Ciais, P., Fader, M., Feely, R. A., Gkritzalis, T., Harris, I., Hauck, J., Ilyina, T., Jain, A. K., Kato, E., Kitidis, V., Klein Goldewijk, K., Koven, C., Landschützer, P., Lauvset, S. K., Lefèvre, N., Lenton, A., Lima, I. D., Metzl, N., Millero, F., Munro, D. R., Murata, A., Nabel, J. E. M. S., Nakaoka, S., Nojiri, Y., O'Brien, K., Olsen, A., Ono, T., Pérez, F. F., Pfeil, B., Pierrot, D., Poulter, B., Rehder, G., Rödenbeck, C., Saito, S., Schuster, U., Schwinger, J., Séférian, R., Steinhoff, T., Stocker, B. D., Sutton, A. J., Takahashi, T., Tilbrook, B., van der Laan-Luijkx, I. T., van der Werf, G. R., van Heuven, S., Van- demark, D., Viovy, N., Wiltshire, A., Zaehle, S., and Zeng, N.: Global Carbon Budget 2015, Earth Syst. Sci. Data, 7, 349-396, doi:10.5194/essd-7-349-2015, 2015.

Lepers, E., Lambin, E. F., Janetos, A. C., DeFries, R., Achard, F., Ramankutty, N., and Scholes, R. J.: A Synthesis of Information on Rapid Land-cover Change for the Period 1981-2000, BioScience, 55, 115-124, 2005.

Li, Y. C.: Land cover dynamic changes in northern China: 19892003, J. Geogr. Sci., 18, 85-94, 2008.

Lindeskog, M., Arneth, A., Bondeau, A., Waha, K., Seaquist, J., Olin, S., and Smith, B.: Implications of accounting for land use in simulations of ecosystem carbon cycling in Africa, Earth Syst. Dynam., 4, 385-407, doi:10.5194/esd-4-385-2013, 2013.

Liu, D. W., Wang, Z. M., Song, K. S., Zhang, B., Hu, L. J., Huang, N., Zhang, S. M., Luo, L., Zhang, C. H., and Jiang, G. J.: Land use/cover changes and environmental consequences in Songnen Plain, Northeast China, Chinese Geogr. Sci., 19, 299-305, 2009.

Luyssaert, S., Jammet, M., Stoy, P. C., Estel, S., Pongratz, J., Ceschia, E., Churkina, G., Don, A., Erb, K., Ferlicoq, M., Gielen, B., Grünwald, T., Houghton, R. A., Klumpp, K., Knohl, A., Kolb, T., Kuemmerle, T., Laurila, T., Lohila, A., Loustau, D., McGrath, M. J., Meyfroidt, P., Moors, E. J., Naudts, K., Novick, K., Otto, J., Pilegaard, K., Pio, C. A., Rambal, S., Rebmann, C., Ryder, J., Suyker, A. E., Varlagin, A., Wattenbach, M., and Dolman, A. J.: Land management and land-cover change have impacts of similar magnitude on surface temperature, Nature Climate Change, 4, 389-393, 2014.

Mahmood, R., Pielke, R. A., Hubbard, K. G., Niyogi, D., Dirmeyer, P. A., McAlpine, C., Carleton, A. M., Hale, R., Gameda, S., Beltran-Przekurat, A., Baker, B., McNider, R., Legates, D. R., Shepherd, M., Du, J. Y., Blanken, P. D., Frauenfeld, O. W., Nair, U. S., and Fall, S.: Land cover changes and their biogeophysical effects on climate, Int. J. Climatol., 34, 929-953, 2014.

Mahmood, R., Pielke, R. A., and McAlpine, C. A.: ClimateRelevant Land Use and Land Cover Change Policies, B. Am. Meteorol. Soc., 97, 195-202, doi:10.1175/BAMS-D-14-00221.1, 2016.

McGuire, A. D., Sitch, S., Clein, J. S., Dargaville, R., Esser, G., Foley, J., Heimann, M., Joos, F., Kaplan, J., Kicklighter, D. W., Meier, R. A., Melillo, J. M., Moore, B., Prentice, I. C., Ramankutty, N., Reichenau, T., Schloss, A., Tian, H., Williams, L. J., and Wittenberg, U.: Carbon balance of the terrestrial biosphere in the twentieth century: Analyses of $\mathrm{CO}_{2}$, climate and land use effects with four process-based ecosystem models, Global Biogeochem. Cy., 15, 183-206, 2001.

Meiyappan, P. and Jain, A. K.: Three distinct global estimates of historical land-cover change and land-use conversions for over 200 years, Front Earth Sci.-Prc., 6, 122-139, 2012.

Meiyappan, P., Jain, A. K., and House, J. I.: Increased influence of nitrogen limitation on $\mathrm{CO}_{2}$ emissions from future land use and land use change, Global Biogeochem. Cy., 29, 1524-1548, 2015.

National Research Council: Advancing Land Change Modeling: Opportunities and Research Requirements, The National Academies Press, Washington, DC, 2014.

Newbold, T., Hudson, L. N., Hill, S. L. L., Contu, S., Lysenko, I., Senior, R. A., Borger, L., Bennett, D. J., Choimes, A., Collen, B., Day, J., De Palma, A., Diaz, S., Echeverria-Londono, S., Edgar, M. J., Feldman, A., Garon, M., Harrison, M. L. K., Alhusseini, T., Ingram, D. J., Itescu, Y., Kattge, J., Kemp, V., Kirkpatrick, L., 
Kleyer, M., Correia, D. L. P., Martin, C. D., Meiri, S., Novosolov, M., Pan, Y., Phillips, H. R. P., Purves, D. W., Robinson, A., Simpson, J., Tuck, S. L., Weiher, E., White, H. J., Ewers, R. M., Mace, G. M., Scharlemann, J. P. W., and Purvis, A.: Global effects of land use on local terrestrial biodiversity, Nature, 520, 45-50, 2015

O’Neill, B. C., Kriegler, E., Ebi, K. L., Kemp-Benedict, E., Riahi, K., Rothman, D. S., van Ruijven, B. J., van Vuuren, D. P., Birkmann, J., Kok, K., Levy, M., and Solecki, W.: The roads ahead: Narratives for shared socioeconomic pathways describing world futures in the 21 st century, Glob. Environ. Chang., 42, 169-180, doi:10.1016/j.gloenvcha.2015.01.004, 2017.

Pielke, R. A., Pitman, A., Niyogi, D., Mahmood, R., McAlpine, C., Hossain, F., Goldewijk, K. K., Nair, U., Betts, R., Fall, S., Reichstein, M., Kabat, P., and de Noblet, N.: Land use/land cover changes and climate: modeling analysis and observational evidence, Wiley Interdisciplinary Reviews, Climate Change, 2, 828-850, 2011

Pitman, A. J., de Noblet-Ducoudre, N., Cruz, F. T., Davin, E. L., Bonan, G. B., Brovkin, V., Claussen, M., Delire, C., Ganzeveld, L., Gayler, V., van den Hurk, B. J. J. M., Lawrence, P. J., van der Molen, M. K., Muller, C., Reick, C. H., Seneviratne, S. I., Strengers, B. J., and Voldoire, A.: Uncertainties in climate responses to past land cover change: First results from the LUCID intercomparison study, Geophys. Res. Lett., 36, L14814, doi:10.1029/2009GL039076, 2009.

Pongratz, J., Reick, C., Raddatz, T., and Claussen, M.: A reconstruction of global agricultural areas and land cover for the last millennium, Global Biogeochem. Cy., 22, GB3018, doi:10.1029/2007GB003153, 2008.

Pongratz, J., Reick, C. H., Houghton, R. A., and House, J. I.: Terminology as a key uncertainty in net land use and land cover change carbon flux estimates, Earth Syst. Dynam., 5, 177-195, doi:10.5194/esd-5-177-2014, 2014.

Popp, A., Calvin, K., Fujimori, S., Havlik, P., Humpenöder, F., Stehfest, E., Bodirsky, B. L., Dietrich, J. P., Doelmann, J. C., Gusti, M., Hasegawa, T., Kyle, P., Obersteiner, M., Tabeau, A., Takahashi, K., Valin, H., Waldhoff, S., Weindl, I., Wise, M., Kriegler, E., Lotze-Campen, H., Fricko, O., Riahi, K., and van Vuuren, D. P.: Land-use futures in the shared socioeconomic pathways, Global Environ. Chang., 42, 331-345, doi:10.1016/j.gloenvcha.2016.10.002, 2017.

Poulter, B., Ciais, P., Hodson, E., Lischke, H., Maignan, F., Plummer, S., and Zimmermann, N. E.: Plant functional type mapping for earth system models, Geosci. Model Dev., 4, 993-1010, doi:10.5194/gmd-4-993-2011, 2011.

Prentice, I. C., Bondeau, A., Cramer, W., Harrison, S. P., Hickler, T., Lucht, W., Sitch, S., Smith, B., and Sykes, M. T.: Dynamic Global Vegetation Modeling: Quantifying Terrestrial Ecosystem Responses to Large-Scale Environmental Change, in: Terrestrial Ecosystems in a Changing World, edited by: Canadell, J. G., Pataki, D. E., and Pitelka, L. F., Springer Berlin Heidelberg, Berlin, Heidelberg, 2007.

Prestele, R., Alexander, P., Rounsevell, M., Arneth, A., Calvin, K., Doelman, J., Eitelberg, D., Engström, K., Fujimori, S., Hasegawa, T., Havlik, P., Humpenöder, F., Jain, A. K., Krisztin, T., Kyle, P., Meiyappan, P., Popp, A., Sands, R. D., Schaldach, R., Schüngel, J., Stehfest, E., Tabeau, A., van Meijl, H., van Vliet, J., and Verburg, P. H.: Hotspots of uncertainty in land use and land cover change projections: a global scale model comparison, Glob. Change Biol., 22, 3967-3983, doi:10.1111/gcb.13337, 2016.

Pugh, T. A. M., Arneth, A., Olin, S., Ahlström, A., Bayer, A. D., Klein Goldewijk, K., Lindeskog, M., and Schurgers, G.: Simulated carbon emissions from land-use change are substantially enhanced by accounting for agricultural management, Environ. Res. Lett., 10, 124008, doi:10.1088/1748-9326/10/12/124008, 2015.

Quaife, T., Quegan, S., Disney, M., Lewis, P., Lomas, M., and Woodward, F. I.: Impact of land cover uncertainties on estimates of biospheric carbon fluxes, Global Biogeochem. Cy., 22, 1-12, doi:10.1029/2007GB003097, 2008.

Ramankutty, N. and Foley, J. A.: Estimating historical changes in global land cover: Croplands from 1700 to 1992, Global Biogeochem. Cy., 13, 997-1027, 1999.

Ramankutty, N., Evan, A. T., Monfreda, C., and Foley, J. A.: Farming the planet: 1 . Geographic distribution of global agricultural lands in the year 2000, Global Biogeochem. Cy., 22, doi:10.1029/2007GB002952, 2008.

Reick, C. H., Raddatz, T., Brovkin, V., and Gayler, V.: Representation of natural and anthropogenic land cover change in MPIESM, J. Adv. Model Earth Sy., 5, 459-482, 2013.

Riahi, K., van Vuuren, D. P., Kriegler, E., Edmonds, J., O’Neill, B. C., Fujimori, S., Bauer, N., Calvin, K., Dellink, R., Fricko, O., Lutz, W., Popp, A., Cuaresma, J. C., Kc, S., Leimbach, M., Jiang, L., Kram, T., Rao, S., Emmerling, J., Ebi, K., Hasegawa, T., Havlik, P., Humpenöder, F., Da Silva, L. A., Smith, S., Stehfest, E., Bosetti, V., Eom, J., Gernaat, D., Masui, T., Rogelj, J., Strefler, J., Drouet, L., Krey, V., Luderer, G., Harmsen, M., Takahashi, K., Baumstark, L., Doelman, J. C., Kainuma, M., Klimont, Z., Marangoni, G., Lotze-Campen, H., Obersteiner, M., Tabeau, A., and Tavoni, M.: The Shared Socioeconomic Pathways and their energy, land use, and greenhouse gas emissions implications: An overview, Global Environ. Chang., 42, 153168, doi:10.1016/j.gloenvcha.2016.05.009, 2017.

Rounsevell, M. D. A., Arneth, A., Alexander, P., Brown, D. G., de Noblet-Ducoudré, N., Ellis, E., Finnigan, J., Galvin, K., Grigg, N., Harman, I., Lennox, J., Magliocca, N., Parker, D., O’Neill, B. C., Verburg, P. H., and Young, O.: Towards decision-based global land use models for improved understanding of the Earth system, Earth Syst. Dynam., 5, 117-137, doi:10.5194/esd-5-1172014, 2014.

Scanlon, B. R., Jolly, I., Sophocleous, M., and Zhang, L.: Global impacts of conversions from natural to agricultural ecosystems on water resources: Quantity versus quality, Water Resour. Res., 43, doi:10.1029/2006WR005486, 2007.

Schmitz, C., van Meijl, H., Kyle, P., Nelson, G. C., Fujimori, S., Gurgel, A., Havlik, P., Heyhoe, E., d'Croz, D. M., Popp, A., Sands, R., Tabeau, A., van der Mensbrugghe, D., von Lampe, M., Wise, M., Blanc, E., Hasegawa, T., Kavallari, A., and Valin, H.: Land- use change trajectories up to 2050: insights from a global agro- economic model comparison, Agr. Econ., 45, 69-84, 2014

Sexton, J. O., Noojipady, P., Song, X.-P., Feng, M., Song, D.-X., Kim, D.-H., Anand, A., Huang, C., Channan, S., Pimm, S. L., and Townshend, J. R.: Conservation policy and the measurement of forests, Nature Clim. Change, 6, 192-196, 2015.

Shevliakova, E., Pacala, S. W., Malyshev, S., Hurtt, G. C., Milly, P. C. D., Caspersen, J. P., Sentman, L. T., Fisk, J. P., Wirth, 
C., and Crevoisier, C.: Carbon cycling under 300 years of land use change: Importance of the secondary vegetation sink, Global Biogeochem. Cy., 23, GB2022, doi:10.1029/2007GB003176, 2009.

Shevliakova, E., Stouffer, R. J., Malyshev, S., Krasting, J. P., Hurtt, G. C., and Pacala, S. W.: Historical warming reduced due to enhanced land carbon uptake, P. Natl. Acad. Sci. USA, 110, 1673016735, 2013.

Sitch, S., Brovkin, V., von Bloh, W., van Vuuren, D., Assessment, B. E. N. E., and Ganopolski, A.: Impacts of future land cover changes on atmospheric $\mathrm{CO}_{2}$ and climate, Global Biogeochem. Cy., 19, GB2013, doi:10.1029/2004GB002311, 2005.

Stocker, B. D. and Joos, F.: Quantifying differences in land use emission estimates implied by definition discrepancies, Earth Syst. Dynam., 6, 731-744, doi:10.5194/esd-6-731-2015, 2015.

Stocker, B. D., Feissli, F., Strassmann, K. M., Spahni, R., and Joos, F.: Past and future carbon fluxes from land use change, shifting cultivation and wood harvest, Tellus B, 66, 23188, doi:10.3402/tellusb.v66.23188, 2014.

Taylor, K. E., Stouffer, R. J., and Meehl, G. A.: An Overview of Cmip5 and the Experiment Design, B. Am. Meteorol. Soc., 93, 485-498, 2012.

Tian, H., Lu, C., Ciais, P., Michalak, A. M., Canadell, J. G., Saikawa, E., Huntzinger, D. N., Gurney, K. R., Sitch, S., Zhang, B., Yang, J., Bousquet, P., Bruhwiler, L., Chen, G., Dlugokencky, E., Friedlingstein, P., Melillo, J., Pan, S., Poulter, B., Prinn, R., Saunois, M., Schwalm, C. R., and Wofsy, S. C.: The terrestrial biosphere as a net source of greenhouse gases to the atmosphere, Nature, 531, 225-228, 2016.

Turner, B. L., Lambin, E. F., and Reenberg, A.: The emergence of land change science for global environmental change and sustainability, P. Natl. Acad. Sci. USA, 104, 20666-20671, 2007.

Van Asselen, S. and Verburg, P. H.: Land cover change or landuse intensification: simulating land system change with a globalscale land change model, Glob. Change Biol., 19, 3648-3667, 2013. van Vuuren, D. P., Edmonds, J., Kainuma, M., Riahi, K., Thomson, A., Hibbard, K., Hurtt, G. C., Kram, T., Krey, V., Lamarque, J. F., Masui, T., Meinshausen, M., Nakicenovic, N., Smith, S. J., and Rose, S. K.: The representative concentration pathways: an overview, Climatic Change, 109, 5-31, 2011.

Verburg, P. H., Neumann, K., and Nol, L.: Challenges in using land use and land cover data for global change studies, Glob. Change Biol., 17, 974-989, 2011.

Verburg, P. H., Mertz, O., Erb, K. H., Haberl, H., and Wu, W. B.: Land system change and food security: towards multi-scale land system solutions, Current Opinion in Environmental Sustainability, 5, 494-502, 2013.

Verburg, P. H., Dearing, J. A., Dyke, J. G., Leeuw, S. V. D., Seitzinger, S., Steffen, W., and Syvitski, J.: Methods and approaches to modelling the Anthropocene, Global Environ. Chang., 39, 328-340, 2015.

Wilkenskjeld, S., Kloster, S., Pongratz, J., Raddatz, T., and Reick, C. H.: Comparing the influence of net and gross anthropogenic land-use and land-cover changes on the carbon cycle in the MPIESM, Biogeosciences, 11, 4817-4828, doi:10.5194/bg-11-48172014, 2014.

Wu, X., Shen, Z. Y., Liu, R. M., and Ding, X. W.: Land Use/Cover Dynamics in Response to Changes in Environmental and SocioPolitical Forces in the Upper Reaches of the Yangtze River, China, Sensors-Basel, 8, 8104-8122, 2008.

Yang, Y. Y., Zhang, S. W., Yang, J. C., Chang, L. P., Bu, K., and Xing, X. S.: A review of historical reconstruction methods of land use/land cover, J. Geogr. Sci., 24, 746-766, 2014.

Zaehle, S., Ciais, P., Friend, A. D., and Prieur, V.: Carbon benefits of anthropogenic reactive nitrogen offset by nitrous oxide emissions, Nat. Geosci., 4, 601-605, 2011.

Zuo, L. J., Zhang, Z. X., Zhao, X. L., Wang, X., Wu, W. B., Yi, L., and Liu, F.: Multitemporal analysis of cropland transition in a climate-sensitive area: a case study of the arid and semiarid region of northwest China, Reg. Environ. Change, 14, 75-89, 2014. 